\title{
Bonus-Driven Repurchases
}

\author{
Yingmei Cheng, Jarrad Harford, and Tianming (Tim) Zhang*
}

\begin{abstract}
Using a large hand-collected database of chief executive officer (CEO) bonus structures, we find that when a CEO's bonus is directly tied to earnings per share (EPS), his company is more likely to conduct a buyback. This effect is especially pronounced when a company's EPS is right below the threshold for a bonus award. Share repurchasing increases the probability the CEO receives a bonus and the magnitude of that bonus, but only when bonus pay is EPS based. Bonus-driven repurchasing firms do not exhibit positive long-run abnormal returns.
\end{abstract}

\section{Introduction}

Annual stock repurchases have increased tremendously since 1982, such that in 2007 total repurchases by industrial firms exceeded $\$ 420$ billion. Skinner (2008) concludes that "repurchases are now the dominant form of payout" (p. 584). Explanations for the rise in repurchases have included flexibility (Guay and Harford (2000), Jagannathan, Stephens, and Weisbach (2000)), tax efficiency, lack of dividend protection on executive options (Fenn and Liang (2001)), and funding of employee stock option exercises (Kahle (2002)). Recent research has also suggested that managers sometimes make suboptimal decisions to repurchase shares (Bens, Nagar, Skinner, and Wong (2003), Hribar, Jenkins, and Johnson (2006)). ${ }^{1}$ However, little work directly examines how managers benefit from such decisions. In this study we examine explicit financial incentives that chief

\footnotetext{
*Cheng, ycheng@business.fsu.edu, Zhang, tzhang@business.fsu.edu, College of Business, Florida State University, Tallahassee, FL 32306; and Harford (corresponding author), jarrad@uw.edu, Foster School of Business, University of Washington, Seattle, WA 98195. We thank an anonymous referee, Hendrik Bessembinder (the editor), and participants at the 2010 Corporate Governance Conference at Drexel University, 2010 China International Conference in Finance, and 2010 Financial Management Association International (FMA) Annual Meeting, and seminar participants at Florida State University, George Mason University, Hong Kong University of Science and Technology, Nanyang Technological University of Singapore, National University of Singapore, Singapore Management University, Tilburg University, University of Florida, University of South Florida, and University of Oklahoma for many helpful comments.

${ }^{1}$ Bens et al. (2003) find that firms shift resources away from real investments toward repurchasing their own stocks, and Hribar et al. (2006) suggest that managers use repurchases as a tool to meet or exceed analysts' EPS forecasts.
} 
executive officers (CEOs) have to manipulate their earnings per share (EPS) through repurchases to increase their bonus payouts.

One reason given by managers for preferring to fund option exercises out of repurchases rather than newly issued shares is a desire to avoid EPS dilution. Thus, managers are acutely aware of the effect of repurchases on the denominator of EPS. According to the survey by Brav, Graham, Harvey, and Michaely (2005), improving EPS numbers is the most frequently mentioned reason for stock repurchases by corporate managers. Many bonus plans are tied to EPS, creating further incentive to decrease shares outstanding through repurchases. ${ }^{2}$ We hypothesize that firms are more likely to undertake share buybacks when their CEO's bonus is tied to EPS. Furthermore, we hypothesize that the probability of firms conducting share repurchases increases when their EPS is right below the threshold EPS that triggers a bonus award. Finally, because the motivation for these repurchases is different, we hypothesize that bonus-driven repurchasing firms will not exhibit positive long-run abnormal returns, in contrast to the findings for repurchases in general (see Ikenberry, Lakonishok, and Vermaelen (1995), Peyer and Vermaelen (2009)).

Using a large hand-collected database of CEO bonus structures, we test these hypotheses. In our sample, we find that $49 \%$ of the CEOs have their bonus tied to EPS and 30\% do not (the rest of the observations either do not have a bonus plan or they do not specify the determining factors of their CEO's bonus). This variation allows us to differentiate a spurious relation between bonuses and repurchases from a more meaningful relation between bonuses and EPS-driven repurchases.

We find that when a CEO's bonus is directly tied to EPS, his company is more likely to conduct a repurchase and the magnitude of the repurchase tends to be larger. We compute what the EPS would be if a firm does not repurchase, that is, the $A S-I F E P S$, and confirm that the EPS-linked bonuses motivate accretive repurchases. When $A S-I F \_E P S$ is right below the threshold EPS for a bonus, $75 \%$ of the observations conduct share buybacks, a significantly higher frequency than normal. Furthermore, when a CEO's bonus is tied to EPS, repurchasing shares has a positive impact on the probability of the CEO receiving a bonus and increases the bonus by $34 \%$ on average.

Bens et al. (2003) show that firms are more likely to repurchase when they cannot achieve the expected growth or market expectation for EPS. In addition, they find that the dilutive effect of employee stock option plans (not just the executive option plans) also affects the firms' decision to buy back shares. We consider these two factors in our multivariate analysis, and although market-driven motivations clearly are important for repurchasing decisions, our results demonstrate that the linking of CEO bonus to EPS has a significant incremental effect on share repurchase beyond market-driven reasons to manage EPS. We also explore the complementary nature of accruals-based earnings management and repurchasing with respect to EPS manipulation.

Furthermore, we find that repurchasing firms, on average, demonstrate positive long-run post-repurchase-announcement abnormal returns, consistent with

\footnotetext{
${ }^{2}$ We discuss reasons why boards write contracts this way in Section II.
} 
Ikenberry et al. (1995) and Peyer and Vermaelen (2009). However, firms with EPS-based bonus plans do not have positive abnormal returns, consistent with the repurchase motivation being bonus manipulation.

We draw on the literature on accounting targets in CEO compensation, beginning with Healy (1985), who hypothesizes that bonus schemes could induce CEOs to manipulate earnings. Studying discretionary earnings accruals and bonus structures of 94 firms, he finds evidence supporting his hypothesis: Accrual policies of managers are related to income-reporting incentives of their bonus contracts. ${ }^{3}$ We investigate how CEO compensation plans influence repurchasing activity for more than 1,000 firms over as long as 15 years. Our focus is on CEOs' motivation to repurchase and their ability to manipulate EPS through such repurchases. Marquardt, Tan, and Young (2010) study managers' decisions to undertake accelerated share repurchases (ASRs) versus open market repurchases (OMRs). ${ }^{4}$ Different from Marquardt et al., we predict a positive relation between the tying of bonuses to EPS and the likelihood of repurchases in general, we focus on the link between CEO bonus structures and annual net repurchasing in the broad sample of industrial firms over 1993-2007 (fiscal years), and we explicitly establish that CEOs benefit from repurchasing when their bonus pay is tied to EPS, creating a purely personal incentive to initiate a repurchase. Thus, we provide a critical piece that has been missing from prior studies on managerial opportunistic behavior around share repurchases.

Our article is also related to studies examining managers' incentives to meet or exceed certain accounting benchmarks by opportunistically engaging in various operating, investing, and financing activities during the fiscal period (e.g., Bange and De Bondt (1998), Bens et al. (2003), Roychowdhury (2006), and Hribar et al. (2006)). However, these studies do not examine the specific benefits managers earn by meeting or exceeding benchmarks. Furthermore, the EPS threshold for bonus awards has several advantages over analysts' EPS expectation, which has been the most commonly used threshold in manipulation studies. ${ }^{5}$ In addition, we show that these EPS-motivated repurchases are different from other repurchases in terms of long-run returns.

Finally, our article is most closely related to the independent work of Young and Yang (2011), who find a positive link between EPS-based bonus plans and

\footnotetext{
${ }^{3}$ Guidry, Leone, and Rock (1999) use business unit data from a multinational conglomerate to reexamine whether earnings-based bonus plans are associated with earnings management.

${ }^{4}$ Using 70 ASR and 201 OMR announcements over 2004-2006, Marquardt et al. (2010) find that firms are more likely to choose ASRs over OMRs when their CEO's bonus compensation is tied to EPS, because of differences in accounting treatments between ASRs and OMRs. However, they do not examine whether CEOs benefit from the repurchasing.

${ }^{5}$ First, analysts keep revising their earnings forecasts up to the day before the earnings announcement, which happens after the end of the fiscal year. By contrast, the EPS threshold for CEO bonus award is set and written into the executive compensation contract at the start of a fiscal year. CEOs may more likely act opportunistically to meet or exceed an ex ante benchmark. Second, managers can exert their influence on analysts and guide analysts' earnings forecasts down to the level they can meet or exceed (Richardson, Teoh, and Wysocki (2004)). In contrast, managers have little influence on the EPS criterion for CEO bonus award once it is set and written into the executive compensation contract at the beginning of the fiscal year. Third, there are variations in analysts' earnings expectations across analysts and over time. The benchmark EPS for CEO bonus award, in contrast, is an objective measure for CEO's performance and a clear target for CEOs to reach.
} 
repurchase likelihood on a smaller sample of U.K. firms. We view their work as complementary, confirming our initial result. Our article then builds on this initial result to show that CEOs directly benefit from the repurchasing. We also document interesting differences between firms that link and do not link bonuses to EPS, allowing for a better understanding of the decision to link bonuses to EPS in the first place. In addition, taking advantage of the large sample size, we find that greater ownership by institutions that have high or median portfolio turnover increases the probability that the CEO's bonus is tied to EPS.

The remainder of the article is organized as follows: The next section discusses and presents the hypotheses. Section III describes our data collection and sample-selection procedures. Section IV reports the empirical tests and results. The study concludes in Section V.

\section{Hypothesis Development}

\section{A. Discussion of the Bonus Contract}

When a CEO's bonus is tied to EPS, he is motivated to repurchase shares to increase his personal wealth. One might wonder why the board writes an incentive contract that can be manipulated. There are several, nonmutually exclusive reasons that explain the existence of such contracts. First, the board may be captured, in which case we would expect measures of governance to vary with the use of EPS-linked bonuses. We test this prediction and find some support for it. Second, the board may completely understand the incentives of the contract and so adjusts the CEO's compensation downward to offset the expected manipulation-driven portion of the bonus. Third, the board may accept the potential for manipulation as a necessary friction in writing a compensation contract that provides the appropriate incentives for value-maximizing investment. That is, the board cannot write a perfect contract and accepts this trade-off to get the investment incentives right. Finally, the board may not realize the potential for manipulation (we prefer not to rely on this explanation, but it does exist).

In Appendix A, we summarize the results from searching the proxies of our sample firms for any discussion of the potential impact of repurchasing on EPS-linked bonuses. Less than $0.5 \%$ of the proxies mention this possibility and even less state that the compensation committee will consider adjusting EPS for the impact of a repurchase in determining bonus eligibility. Instead, the committee typically states that the majority of EPS growth comes from operations, not from repurchases. Furthermore, they state that share repurchases generally benefit shareholders and they could be done for various reasons (e.g., to distribute excess cash to shareholders or to offset the dilution from employee option exercising). It is impossible, or at least very difficult, for the board to write a contract that distinguishes among a number of reasons underlying a repurchase and decides whether to adjust EPS accordingly in a way that would be ex ante agreeable to the CEO.

\section{B. Hypotheses Regarding the Link between Repurchases and Bonuses}

Regardless of the reason behind the bonus contract, we should observe that firms are more likely to repurchase when EPS is one factor in their CEO's 
bonus contract. The typical bonus structure is such that if the level of earnings is less than a lower bound, managers do not receive a bonus. Because repurchases do not have unlimited ability to manipulate EPS, the motivation to use them will be much greater close to the lower bound. ${ }^{6}$ We thus have our first hypothesis:

Hypothesis 1. When its CEO's bonus is tied to EPS, a firm is more likely to repurchase shares; firms are more likely to conduct share repurchases when their EPS is less than but close to the level that triggers the bonus.

A share buyback should have a positive impact on a CEO's bonus when the bonus is tied to EPS. The impact can be measured in terms of the probability of a bonus award and the magnitude of the bonus. We thus have our second hypothesis:

Hypothesis 2. When a CEO's bonus is tied to EPS, share repurchases will increase the bonus, in terms of both the probability of a bonus award and the magnitude of the bonus.

Given Healy's (1985) findings, it is natural to wonder why firms simply do not manage earnings to reach bonus thresholds rather than repurchasing. Although the two approaches could be viewed as substitute methods, they are not mutually exclusive and could be used as complements. In the Empirical Results section, we explicitly examine whether the two methods are used together, whether repurchases are a last resort after exhausting accrual-based earnings management, or whether different firms use each approach.

\section{Additional Hypotheses}

The extant literature has provided several hypotheses on why a firm conducts a share buyback, including distributing excess cash, achieving target leverage ratio, avoiding a takeover, avoiding stock option dilution, and signaling undervaluation. We discuss these hypotheses in detail in the next section and control for them in the empirical tests. If the primary motivation of the repurchases is to positively affect EPS for CEOs' personal gain, then typically observed effects, such as the positive long-run abnormal returns documented by Ikenberry et al. (1995), will be absent. Thus, we have the following hypothesis:

Hypothesis 3. When CEO bonus is determined by EPS, shares of the repurchasing firms have similar returns in the postbuyback period to shares of matching nonrepurchasing firms. ${ }^{7}$

Evidence in favor of this hypothesis would provide further support for our conclusion that these repurchases are driven by bonus manipulation.

\footnotetext{
${ }^{6}$ Very few firms disclose the maximum bonus limit and they generally do not disclose the exact payoff function of bonus between minimum and maximum EPS. Because of the lack of necessary data, we do not empirically explore whether CEOs manipulate EPS via repurchasing when EPS (without a buyback) is between the minimum threshold and the maximum limit for bonus.

${ }^{7}$ As documented in numerous studies, the announcements of repurchasing plans are usually accompanied by positive reaction from the stock market. At the first glance, it seems natural to compare the short-term market reaction around the announcement of stock repurchases for EPS-linking versus non-EPS-linking firms. However, this is a weak test: The authorizations of repurchasing are often made and announced well in advance of the decision to repurchase and/or manipulate, so it would be very hard for the market to know if this is a "bad" authorization at the time of announcement.
} 


\section{Data Sources, Sample Selection, and Descriptive Statistics}

\section{A. Sample Selection}

We start with ExecuComp, which provides detailed information on the compensation of the top five executives of S\&P 1500 firms since 1992. We obtain these firms' financial information from Compustat's Industrial Annual database. ${ }^{8}$ We exclude financial and utilities companies, firms with negative book value of equity, and firms with share price less than $\$ 1$. There are 17,555 firm-year observations from 1992 to 2007 in the merged Compustat-ExecuComp sample.

To obtain specific details on CEOs' bonus structures, we extract the annual proxy statements (DEF 14A) filed by the firms from the U.S. Securities and Exchange Commission (SEC) Web site (www.sec.gov). The electronic filings on the SEC Web site start from 1994, providing proxy statements filed between 1994 and 2008 (fiscal years 1993-2007). After matching the proxy statements with our merged Compustat-ExecuComp sample, we have 12,476 firm-year observations by 1,423 companies in the final sample, from 1993 to 2007 (fiscal years).

\section{B. Data Collection on CEOs' Bonus Structures}

We read all 12,476 proxy statements and collect information on the bonus structures of CEOs. The common practice is that the bonus is a performancebased incentive plan that is paid in cash shortly after the end of the fiscal year. The compensation committee decides the criteria of the bonus award at the beginning of the fiscal year. Some companies provide a very detailed description of the evaluating factors that determine the CEO bonus in their SEC filings, and some are vague about the process. Bonus calculations vary among firms, but generally no bonuses are payable if the threshold goals are not attained. That is, if the CEO's performance is below a minimum level of the measures, he will not receive a cash bonus; if his performance meets the minimum criteria, he is eligible to receive a bonus. For illustration purposes, in Appendix B we present one example from the proxy statement of P. F. Chang's China Bistro Inc., filed Mar. 13, 2008.

We collect the following data items on the CEO bonus:

i) Whether EPS is one factor in determining the bonus;

ii) If EPS is a factor, the threshold EPS for the CEO to receive a bonus;

iii) The target ratio of the bonus to the base salary of the CEO, which is the ex ante expected level of bonus divided by the base salary.

A CEO's bonus is often tied to EPS (e.g., Matsunaga and Park (2001)). As shown in Panel A of Table 1, about $2.3 \%$ of the observations do not have

\footnotetext{
${ }^{8}$ Compustat adopts a new version of data format, starting from fiscal year 2007. One of the main changes in the new version is that the data are labeled by abbreviated letter names, not by item numbers. For example, "total assets" is named "AT" in the new version, not "item 6" as in the old version. To be comparable with the previous work (e.g., Skinner (2008)), we describe the data by their item numbers in our analysis, although our sample covers fiscal year 2007.
} 
a bonus component in the CEO compensation. In around $19 \%$ of our sample, the firms do not specify the evaluating factors for bonus award; thus, we are unable to determine whether EPS is a factor in the bonus decision. About $49 \%$ of the firms have a bonus component that is tied directly to EPS, and about $30 \%$ do not tie the bonus to EPS.

In Panel B of Table 1, we report the probability of within-firm 1-year transition among the above four types. The within-firm bonus structures are stable over time. If a firm does not link CEO bonus to EPS in year $t$, its probability of not linking CEO bonus to EPS in year $t+1$ is, on average, $86.85 \%$. If the CEO bonus is based on EPS in year $t$, the probability of the CEO bonus depending on EPS in year $t+1$ is, on average, $92.80 \%$.

\section{TABLE 1}

Summary of the Bonus Structures of CEOs

Panel A of Table 1 summarizes the frequency of whether earnings per share (EPS) is a factor in determining chief executive officer (CEO) bonus. The information is collected from proxy statements (DEF 14A) available on the U.S. Securities and Exchange Commission (SEC) Web site (www.sec.gov), starting from 1994. Panel B reports the within-firm 1-year transition probabilities of EPS linking.

Panel A. Distribution Frequency of Whether EPS Is a Factor in Determining CEO Bonus

\begin{tabular}{|c|c|c|c|c|}
\hline Cases & & No. of Obs. & & Frequency \\
\hline $\begin{array}{l}\text { There is no bonus component in CEO compensation } \\
\text { Cannot determine } \\
\text { EPS is not a factor in CEO bonus } \\
\text { EPS is a factor in CEO bonus }\end{array}$ & & $\begin{array}{r}283 \\
2,357 \\
3,711 \\
6,125\end{array}$ & & $\begin{array}{r}2.27 \% \\
18.87 \% \\
29.75 \% \\
49.00 \%\end{array}$ \\
\hline Total & & 12,476 & & $100.00 \%$ \\
\hline \multicolumn{5}{|l|}{ Panel B. Within-Firm 1-Year Transition Matrix } \\
\hline Cases & $\begin{array}{l}\text { There Is No Bonus } \\
\text { Component in CEO } \\
\text { Compensation } \\
\end{array}$ & $\begin{array}{c}\text { Cannot } \\
\text { Determine } \\
\end{array}$ & $\begin{array}{c}\text { EPS Is Not a } \\
\text { Factor in CEO } \\
\text { Bonus } \\
\end{array}$ & $\begin{array}{l}\text { EPS Is a } \\
\text { Factor in CEO } \\
\text { Bonus } \\
\end{array}$ \\
\hline $\begin{array}{l}\text { There is no bonus component in CEO compensation } \\
\text { Cannot determine } \\
\text { EPS is not a factor in CEO bonus } \\
\text { EPS is a factor in CEO bonus }\end{array}$ & $\begin{array}{r}86.85 \% \\
0.29 \% \\
0.16 \% \\
0.11 \%\end{array}$ & $\begin{array}{r}5.98 \% \\
76.22 \% \\
6.06 \% \\
3.22 \%\end{array}$ & $\begin{array}{r}3.59 \% \\
10.86 \% \\
86.51 \% \\
3.87 \%\end{array}$ & $\begin{array}{r}3.59 \% \\
12.63 \% \\
7.28 \% \\
92.80 \%\end{array}$ \\
\hline
\end{tabular}

Figure 1 plots the distribution of the four types over time. The percentage of firms that do not have a bonus component in CEO compensation remains around $2 \%$. Over time, firms provide more detailed information on bonus determinants in their proxy statements, so the fraction of firms in the group of "cannot determine" decreases, especially in recent years. The group of firms that link CEO bonus to EPS has increased since 2002, outpacing the increase of the firms that do not use EPS as a determining factor of CEO bonus.

About $20 \%$ of the proxy statements explicitly specify the target bonus ratio for their CEOs, which is the expected level of bonus divided by salary. Figure 2 plots the average target bonus-to-salary ratio for each fiscal year from 1993 to 2007. The target bonus-to-salary ratio exhibits great growth from the 1990 s to 2000s. In 2007, the target bonus was, on average, about $105 \%$ of the salary. This demonstrates the economic significance of the bonus in CEO compensation as it represents a substantial amount of income for CEOs. Furthermore, even for ostensibly wealthy CEOs, the bonus provides much of the liquid wealth in any given year, as most of these CEOs' wealth is in unexercisable options or restricted stock. 
FIGURE 1

Time Series of EPS Bonus Linking

Figure 1 plots the fraction of observations in each of the four categories indicating whether earnings per share (EPS) is a factor in chief executive officer (CEO) bonus (EPS Is Not a Factor, EPS Is a Factor, There Is No Bonus Component, and Cannot Determine) from 1993 to 2007 (fiscal years). The information is collected from the proxy statements (DEF 14A) available on the U.S. Securities and Exchange Commission Web site (www.sec.gov), starting from 1994 (calendar year).

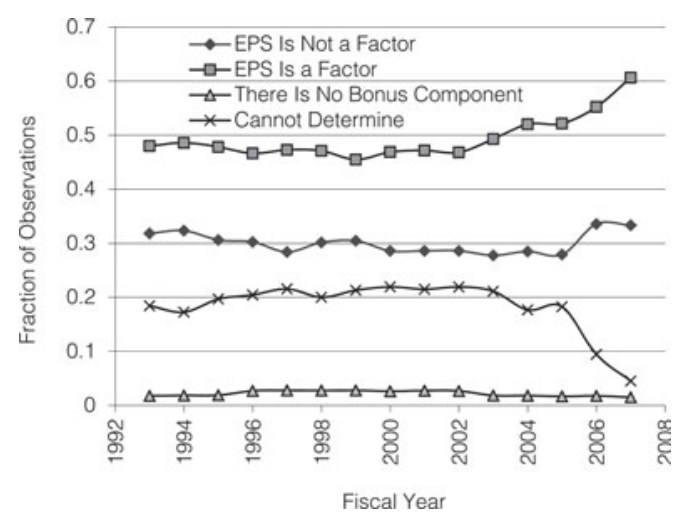

FIGURE 2

Average Target Bonus-to-Salary Ratio by Year

Figure 2 plots the average target bonus-to-salary ratio from 1993 to 2007 (fiscal years). The target bonus-to-salary ratio is specified by the compensation committee at the beginning of the fiscal year. The information is collected from the proxy statements (DEF 14A) available on the U.S. Securities and Exchange Commission Web site (www.sec.gov).

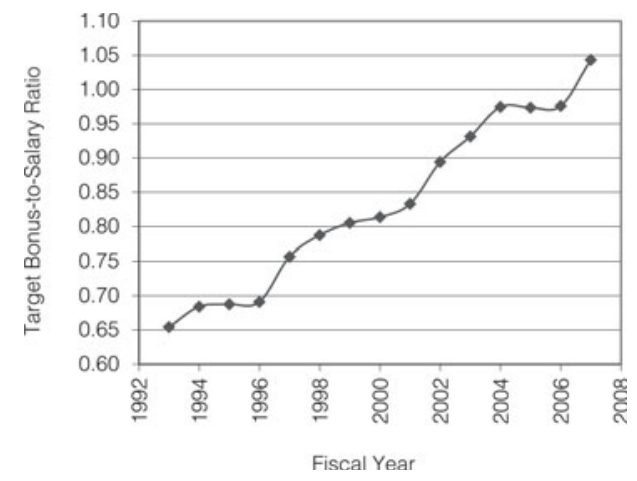

We begin by testing the first part of Hypothesis 1 on the large panel data set. After establishing the general effect in the large panel, we move to the second part of Hypothesis 1, which is a more precise statement about the link between bonus design and repurchase decisions. However, we are limited to only a few hundred observations for that test. Among the firms that base CEO bonus on EPS, the majority do not disclose the threshold EPS, often treating it as confidential business information they do not want to make available to their competitors. For example, Cypress Semiconductor Corp., in their proxy statement of fiscal year 2007, says, "The details of the specific earnings per share target have not been included in this proxy statement in order to maintain the confidentiality of our earnings per share expectations, which we believe are confidential commercial or business information, the disclosure of which would adversely affect the Company." 
For about $7 \%$ of the observations that tie their CEO bonus directly to EPS, we found the threshold EPS for CEOs to receive a bonus: The threshold EPS is disclosed by 185 firms in 402 firm-year observations. Among the observations that disclose threshold EPS for the bonus award, we collect the bonus-to-salary ratio when EPS meets the threshold. The mean is $41.64 \%$ and the median is $40 \%$, suggesting that the CEO stands to receive significant monetary benefit when EPS meets the threshold.

To ease the concern of a potential sample-selection bias, we compare the firms that disclose threshold EPS with firms that do not. We find there are no statistically significant differences between the two groups in terms of size, cash flow, profitability, dividend-payout ratio, market to book, leverage, and industryadjusted leverage. Therefore, there is no reason for us to believe that these two groups are fundamentally different from each other.

\section{Measuring Share Buyback and Firm Characteristics}

Following Fama and French (2001) and Skinner (2008), we measure share buyback as net repurchases. ${ }^{9}$ We calculate the net repurchases as the increase in common treasury stock (Compustat item 226). Treasury stock captures the cumulative effects of stock repurchases and reissues. If treasury stock is 0 in the current and prior years, we measure net repurchases as the difference between stock purchase (item 115) and stock issuance (item 108). If either the change in treasury stock or the difference between item 115 and item 108 is negative, net repurchases are set to 0 . As discussed by Skinner, it is preferable to use the change in treasury stock, if available, rather than net purchases (item 115 - item 108) because the change in treasury stock nets out any associated issuances, including noncash issuances. We use both dollar amount of repurchases and scaled repurchases (dollar amount of repurchases divided by prior year-end market value of equity).

We consider the various determinants of repurchases, based on the extant theories in the literature: i) distribution of excess cash hypothesis (e.g., Jensen (1986), Easterbrook (1984), Guay and Harford (2000), Jagannathan et al. (2000), and Grullon and Michaely (2002)), ii) target leverage ratio hypothesis (Bagwell and Shoven (1988), Opler and Titman (1996), and Lie (2002)), iii) takeover avoidance hypothesis (Denis (1990), Bagwell (1991), and Brown and Ryngaert (1991)), iv) management stock option dilution hypothesis, and v) signaling or undervaluation hypothesis (e.g., Vermaelen (1981), John and Williams (1984), Brennan and Thakor (1990), and Lucas and McDonald (1998)). Bens et al. (2003) show that firms are more likely to repurchase when they cannot achieve expected growth or the market expectation for EPS. In addition, they find that the dilutive effect of broad employee stock option plans affects a firm's decision to buy back shares. Following Bens et al., we construct a dummy variable, Below_EPS_Growth, which is the same as NUM_POS from their paper. It is 1 if earnings in year $t$ are less than earnings in year $t-1$ multiplied by the expected growth rate of EPS,

\footnotetext{
${ }^{9}$ Banyi, Dyl, and Kahle (2008) measure share repurchases as the purchase of common and preferred stock (item 115, PRSTKC) minus any reduction in the value of net number of preferred stocks outstanding (item 56, PSTKRV). We check the robustness of our results by using the approach in Banyi et al., and our results do not change qualitatively.
} 
and 0 otherwise. The expected growth rate of EPS is approximated by the growth rate of EPS from years $t-2$ to $t-1$. We expect the dummy variable to be significantly and positively related to firms' share repurchases. Compustat began reporting on broad employee stock option plans in 2004. We scale employee option exercises during year $t$ by the shares outstanding as of the end of year $t-1$. If employee stock option plans affect share repurchasing, we expect this variable to be positively related to repurchasing.

\title{
D. Descriptive Statistics
}

Table 2 provides preliminary statistics of firm characteristics, CEO bonus, and the magnitude of share repurchases. All dollar amounts are adjusted to 1992

TABLE 2

Summary Statistics for Firm Characteristics, CEO Bonus, and Share Repurchase

\begin{abstract}
Table 2 provides summary statistics on firm characteristics, chief executive officer (CEO) bonus, and magnitude of share repurchase. We calculate the net repurchase as the increase in common treasury stock (Compustat item 226). If treasury stock is 0 in the current and prior years, we measure repurchases as the difference between stock purchase (item 115) and stock issuance (item 108). If either of these two amounts is negative, repurchases are set to 0 . All dollar amounts are in 1992 dollars. Total assets is the total book value of the assets. Cash is the amount of cash and cash equivalents scaled by the book value of assets. Profitability is the ratio of net income to total assets. Payout ratio is the dividend paid scaled by net income. Leverage is the sum of long-term debt and debt in current liabilities scaled by the book value of assets. Industry-adjusted leverage is the difference between a firm's leverage ratio and the median leverage ratio of all firms in the same industry (Fama-French (1993) 48-industry classification is used). Takeover is 1 for firms that are targets of acquisition attempts or rumor of acquisition attempts in the current or prior fiscal year, and 0 otherwise. Market to book is the ratio of the market value of equity plus debt to the book value of assets. Abnormal return is the market-adjusted abnormal return within 1 year before the beginning of the current fiscal year. 1-year return to shareholders is the stock return during the 12 months of the fiscal year. Management options is the number of shares underlying options held by the top five executives scaled by the number of shares outstanding. Below_EPS_Growth equals 1 if current-period earnings are less than last-period earnings multiplied by the expected EPS growth rate, and 0 otherwise. The expected EPS growth rate is approximated by the EPS growth rate from years $t-2$ to $t-1$. ESO_EX is the employee options exercised during the year divided by the shares outstanding as of the end of last year. Dummy of bonus award is 1 if the amount of bonus is positive, and 0 otherwise. Bonus is the amount of bonus received by the CEO. Bonus divided by cash pay is the amount of bonus scaled by the amount of cash pay received by the CEO. Cash pay is the sum of salary, bonus, and other annual income. Buy is 1 if net repurchase is positive, and 0 otherwise. Amount of buyback is the value of net repurchase. Buyback ratio is the amount of buyback divided by the lagged market value of equity. Column 2 summarizes the variables in the whole sample, grouped by their motivating hypotheses from the extant literature. Columns 3 and 4 compare nonrepurchasing versus repurchasing firms. ${ }^{* *}$ and ${ }^{* * *}$ indicate that repurchasing firms are significantly different from nonrepurchasing firms at the $5 \%$ and $1 \%$ levels, respectively, under the Kruskal-Wallis (1952) test.
\end{abstract}

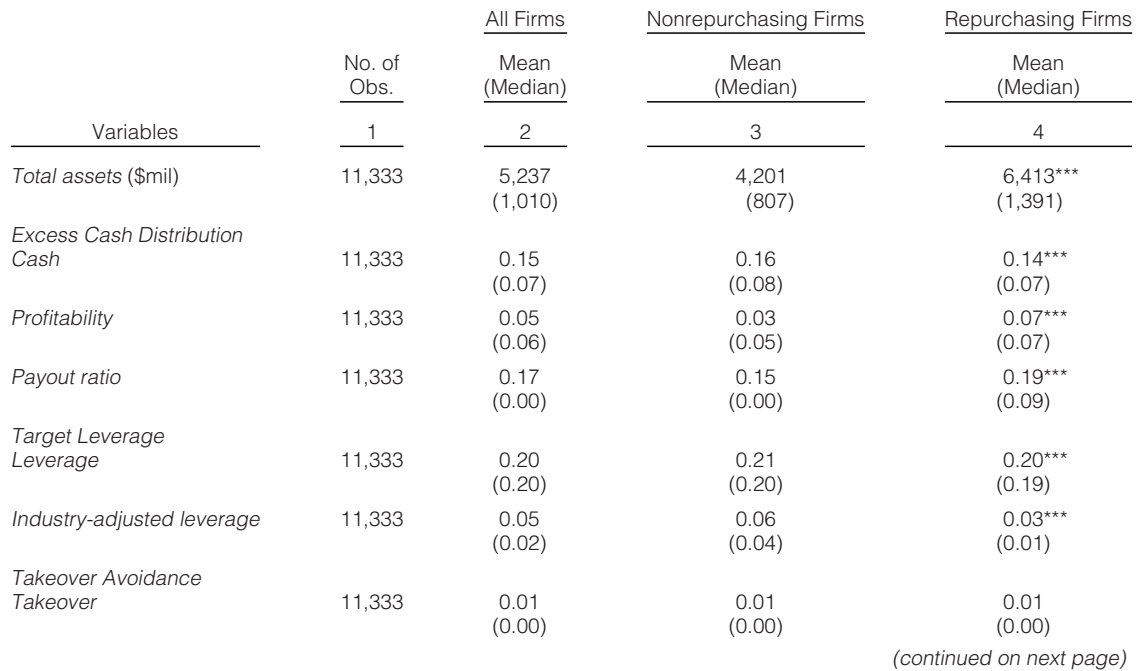


TABLE 2 (continued)

Summary Statistics for Firm Characteristics, CEO Bonus, and Share Repurchase

\begin{tabular}{|c|c|c|c|c|}
\hline & & All Firms & $\underline{\text { Nonrepurchasing Firms }}$ & $\underline{\text { Repurchasing Firms }}$ \\
\hline & $\begin{array}{l}\text { No. of } \\
\text { Obs. }\end{array}$ & $\begin{array}{c}\text { Mean } \\
\text { (Median) } \\
\end{array}$ & $\begin{array}{c}\text { Mean } \\
\text { (Median) }\end{array}$ & $\begin{array}{c}\text { Mean } \\
\text { (Median) }\end{array}$ \\
\hline Variables & 1 & 2 & 3 & 4 \\
\hline $\begin{array}{l}\text { Signaling/Undervaluation } \\
\text { Market to book }\end{array}$ & 11,333 & $\begin{array}{c}1.98 \\
(1.43)\end{array}$ & $\begin{array}{c}2.02 \\
(1.51)\end{array}$ & $\begin{array}{l}1.93^{\star \star \star} \\
(1.37)\end{array}$ \\
\hline Abnormal return & 11,333 & $\begin{array}{l}12.75 \% \\
(0.14 \%)\end{array}$ & $\begin{array}{l}17.11 \% \\
(0.85 \%)\end{array}$ & 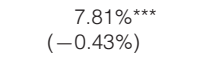 \\
\hline 1-year return to shareholders & 11,333 & $\begin{array}{l}22.47 \% \\
(12.12 \%)\end{array}$ & $\begin{array}{c}24.92 \% \\
(12.28 \%)\end{array}$ & $\begin{array}{l}19.69 \%{ }^{* \star} \\
(11.95 \%)\end{array}$ \\
\hline $\begin{array}{l}\text { Option Dilution } \\
\text { Management options }\end{array}$ & 11,333 & $\begin{array}{c}0.029 \\
(0.023)\end{array}$ & $\begin{array}{c}0.031 \\
(0.025)\end{array}$ & $\begin{array}{l}0.027^{\star \star \star} \\
(0.021)\end{array}$ \\
\hline ESO_EX & 2,459 & $\begin{array}{c}0.018 \\
(0.014)\end{array}$ & $\begin{array}{c}0.018 \\
(0.013)\end{array}$ & $\begin{array}{l}0.018^{\star \star} \\
(0.015)\end{array}$ \\
\hline $\begin{array}{l}\text { Meet Expectations } \\
\text { Below_EPS_Growth }\end{array}$ & 7,612 & $\begin{array}{c}0.58 \\
(1.00)\end{array}$ & $\begin{array}{c}0.56 \\
(1.00)\end{array}$ & $\begin{array}{l}0.59^{\star *} \\
(1.00)\end{array}$ \\
\hline $\begin{array}{l}\text { Bonus Variables } \\
\text { Dummy of bonus award } \\
\text { ( } 1 \text { if bonus }>0,0 \text { otherwise })\end{array}$ & 11,333 & $\begin{array}{c}0.69 \\
(1.00)\end{array}$ & $\begin{array}{c}0.68 \\
(1.00)\end{array}$ & $\begin{array}{l}0.70^{* \star *} \\
(1.00)\end{array}$ \\
\hline Bonus (\$thousand) & 11,333 & $\begin{array}{l}565.90 \\
(250.00)\end{array}$ & $\begin{array}{c}476.07 \\
(204.35)\end{array}$ & $\begin{array}{l}667.83^{\star \star \star} \\
(317.14)\end{array}$ \\
\hline Bonus divided by cash pay & 11,333 & $\begin{array}{c}0.31 \\
(0.35)\end{array}$ & $\begin{array}{c}0.30 \\
(0.32)\end{array}$ & $\begin{array}{l}0.33^{* * *} \\
(0.38)\end{array}$ \\
\hline $\begin{array}{l}\text { Repurchase Variables } \\
\text { Buy (1 if net repurchase, } 0 \text { otherwise) }\end{array}$ & 11,333 & $\begin{array}{c}0.47 \\
(0.00)\end{array}$ & $\begin{array}{c}0.00 \\
(0.00)\end{array}$ & $\begin{array}{l}1.00^{* \star *} \\
(1.00)\end{array}$ \\
\hline Amount of buyback (\$mil) & 11,333 & $\begin{array}{l}84.88 \\
(0.00)\end{array}$ & $\begin{array}{c}0.00 \\
(0.00)\end{array}$ & $\begin{array}{l}181.18^{\star \star \star} \\
(22.97)\end{array}$ \\
\hline Buyback ratio & 11,333 & $\begin{array}{l}1.42 \% \\
(0.00)\end{array}$ & $\begin{array}{c}0.00 \\
(0.00)\end{array}$ & $\begin{array}{l}3.02 \%{ }^{\star \star \star} \\
(1.81 \%)\end{array}$ \\
\hline
\end{tabular}

dollars by using the consumer price index (CPI). ${ }^{10}$ Column 2 summarizes the variables in the whole sample. Forty-seven percent of the firm-year observations have positive net repurchases. The fraction of repurchasing firms has increased over time (from 39\% in 1993 to $64 \%$ by 2007 in our sample). Bonus is substantial: about $31 \%$ (mean) or $35 \%$ (median) of the cash compensation (the sum of salary, bonus, and other annual pay). Total assets, abnormal return, 1-year return to shareholders, management options, and bonus have large outliers. Therefore, in our multivariate analysis, we winsorize these variables at the 1st and 99th percentiles to reduce potential impact caused by a few outliers.

In columns 3 and 4 of Table 2, we compare firm characteristics and CEO bonus between repurchasing and nonrepurchasing firms. The CEOs in the repurchasing firms receive a larger bonus than those in nonrepurchasing firms, although repurchasing firms have smaller 1-year returns in the current year than nonrepurchasing firms.

Note that, on average, repurchasing firms have lower management options than nonrepurchasing firms, seemingly contradicting the positive relation between repurchases and management options documented by Fenn and Liang (2001).

\footnotetext{
${ }^{10} \mathrm{CPI}$ data are taken from the Web site of Bureau of Labor Statistics: http://www.bls.gov/cpi/
} 
However, repurchasing firms are also significantly larger than nonrepurchasing firms, and firm size is negatively related to management options. In the multivariate analysis, controlling for firm size and other firm characteristics, we observe the expected positive relation between repurchases and management options.

The average amount of buyback by repurchasing firms is $\$ 181.18$ million, and the average buyback ratio is $3.02 \%$. This is economically significant: Assuming that EPS without repurchase is about $\$ 3.80$ /share (the average reported EPS is $\$ 3.84 /$ share in the sample), a $3.02 \%$ reduction in the number of shares outstanding can increase EPS by up to 11 cents per share. This translates to a significant payoff for CEOs. For example, Watsco Inc., in its proxy for fiscal year 2006, explicitly specifies that, for every 1 cent increase in EPS, its CEO will be awarded $\$ 65,250$ in annual bonus, conditional on the threshold EPS goal being met.

\section{Empirical Analysis and Results}

We now test the hypotheses developed in Section II. Our primary hypothesis is that firms with EPS-linked CEO bonuses are more likely to repurchase shares. We start with a simple comparison of firms with EPS-linked and non-EPS-linked bonuses. We show that firms with and without EPS linking differ, so we control for their self-selection into EPS linking and then examine the effect of EPS linking on share buyback in a multivariate setting. We further study the effect in the subsample of firms for which we can identify the bonus threshold and find that the effect is especially pronounced when the firm is close to the bonus threshold. We close the loop by showing that CEOs benefit: Their bonuses are higher when they repurchase. We then provide additional evidence consistent with our hypothesis: Specifically, the long-run stock performance on EPS-linked repurchasing firms is not abnormally positive as it is for other repurchasing firms. Finally, we discuss how repurchase-driven EPS manipulation relates to accruals-based earnings management.

\section{A. Share Repurchases and Tying CEO Bonus to EPS}

In Table 3, we compare the frequency of buyback, the dollar amount of buyback, and the buyback ratio in the two groups: those tying EPS to CEO bonus and those not. In the group with CEO bonus tied to EPS, the frequency of buyback is $52 \%$, significantly higher than the $41 \%$ found in the counterpart group. The difference in the frequency of buyback in the two groups is $11 \%$. An $11 \%$ increase from a $41 \%$ base is economically significant. The dollar amount and relative size of the buyback are also significantly greater in the former group than in the latter.

However, firms with the CEO bonus linked to EPS can be different from those without. That is, we need to consider the self-selection of the firms into different bonus contracts. To compare the two groups of firms, we collect information on corporate governance measures, which are indicators of managerial power, in addition to the financial characteristics such as total assets, cash, leverage, and so on. The first measure of governance is Gompers, Ishii, and Metrick's (2003) Governance Index (GIndex), based on 24 possible antitakeover provisions. 
TABLE 3

Share Buyback and Linking CEO Bonus to EPS

Table 3 compares the frequency of positive buyback, the magnitude of buyback, and the scaled buyback in two groups: firms that tie earnings per share (EPS) to chief executive officer (CEO) bonus versus firms that do not tie EPS to CEO bonus. $n$ is the number of observations.

\begin{tabular}{|c|c|c|c|c|}
\hline & & $\begin{array}{c}\text { Net Repurchase } \\
\text { (1 if Positive, } \\
0 \text { Otherwise) } \\
\end{array}$ & $\begin{array}{c}\text { Amount of } \\
\text { Buyback } \\
(\$ \text { mil }) \\
\end{array}$ & $\begin{array}{c}\text { Net Repurchases } \\
\text { Scaled by Market } \\
\text { Value of } \\
\text { Equity }(\%) \\
\end{array}$ \\
\hline Groups & $n$ & $\begin{array}{c}\text { Mean } \\
\text { (Median) }\end{array}$ & $\begin{array}{c}\text { Mean } \\
\text { (Median) } \\
\end{array}$ & $\begin{array}{c}\text { Mean } \\
\text { (Median) }\end{array}$ \\
\hline EPS is a factor in CEO bonus & 6,125 & $\begin{array}{c}0.52 \\
(1.00)\end{array}$ & $\begin{array}{c}114.60 \\
(0.14)\end{array}$ & $\begin{array}{c}1.60 \\
(0.02)\end{array}$ \\
\hline EPS is not a factor in CEO bonus & 3,711 & $\begin{array}{c}0.41 \\
(0.00)\end{array}$ & $\begin{array}{l}43.76 \\
(0.00)\end{array}$ & $\begin{array}{c}1.20 \\
(0.00)\end{array}$ \\
\hline $\begin{array}{l}t \text {-test: } t \text {-statistic } \\
\text { ( } p \text {-value) }\end{array}$ & & $\begin{array}{c}10.37 \\
(<0.0001)\end{array}$ & $\begin{array}{c}8.56 \\
(<0.0001)\end{array}$ & $\begin{array}{c}6.84 \\
(<0.0001)\end{array}$ \\
\hline $\begin{array}{l}\text { Kruskal-Wallis test: } \chi^{2} \\
\text { ( } p \text {-value) }\end{array}$ & & $\begin{array}{l}106.34 \\
(<0.0001)\end{array}$ & $\begin{array}{l}185.07 \\
(<0.0001)\end{array}$ & $\begin{array}{l}106.88 \\
(<0.0001)\end{array}$ \\
\hline
\end{tabular}

The Investor Responsibility Research Center database provides annual information on corporate antitakeover provisions for 1990, 1993, 1995, 1998, 2000, 2002, 2004,2006 , and 2008. We fill in observations in the missing years using information from the most recent year with data. A greater value of GIndex corresponds to weaker shareholder rights and stronger managerial power.

The second measure of governance relates to external monitoring, proxied by the ratio of shares owned by the institutions divided by the total number of shares outstanding. The data source is the Thomson Financial Institutional Ownership database. Greater institutional ownership may provide better monitoring and mitigate the problems associated with managerial opportunism (Shleifer and Vishny (1986), Jensen (1993)). We also control for the turnover of institutional holdings, and we expect that higher turnover is associated with weaker monitoring by institutional investors. An institution's portfolio turnover is measured as the following: $\sum\left|\Delta w_{k, t}\right| /\left(\sum w_{k, t}+\sum w_{k, t-1}\right)$, with $w_{k, t}\left(w_{k, t-1}\right)$ being the portfolio weight in firm $k$ at the end of fiscal year $t(t-1)$ computed as shares held times stock price, and $\Delta w_{k, t}=w_{k, t}-w_{k, t-1}$. Following Bushee (1998), if an institution's portfolio turnover is above the 75th percentile among all institutions, it is classified as "transient"; if an institution's portfolio turnover is below the 10th percentile among all institutions, it is classified as "dedicated"; the rest are classified as "quasi-indexers." Q5 (transient, quasi-indexer, or dedicated) equals 1 if the firm is ranked in the top quintile of proportional ownership of individual firms by the group of transient institutions, quasi-indexer institutions, and dedicated institutions, respectively.

Panel A of Table 4 compares the characteristics of the two groups. EPSlinking firms are larger and more profitable, with higher dividend payout ratios and leverage ratios, suggesting more mature firms. However, it also appears that some growth firms link CEO bonus to EPS because EPS-linking firms also have smaller cash holdings and higher market-to-book ratios. EPS-linking firms have higher GIndex and lower institutional holdings than non-EPS-linking firms, suggesting that EPS-linking firms have weaker corporate governance than 
non-EPS-linking firms. Panel A also shows that EPS-linking firms are more likely to have a large proportion of their stock held by institutions that are classified as quasi-indexers.

\section{TABLE 4}

\section{Self-Selection of EPS Linking}

Panel A of Table 4 compares the characteristics of two groups of firms: those with chief executive officer (CEO) bonus linked to earnings per share (EPS) and those not. GIndex is obtained from the Investor Responsibility Research Center governance data, as constructed by Gompers et al. (2003). Institutional holding is the ratio of shares owned by institutions divided by the total number of shares outstanding (the source is the Thomson Financial Institutional Ownership database). An institution's portfolio turnover is measured as the following: $\sum\left|\Delta w_{k, t}\right| /\left(\sum w_{k, t}+\sum w_{k, t-1}\right)$, where $w_{k, t}\left(w_{k, t-1}\right)$ is the portfolio weight (shares held times stock price) in firm $k$ at the end of fiscal year $t(t-1)$, and $\Delta w_{k, t}=w_{k, t}-w_{k, t-1}$. If an institution's portfolio turnover is above the 75th percentile among all institutions, it is classified as "transient"; if an institution's portfolio turnover is below the 10th percentile among all institutions, it is classified as "dedicated"; the rest are classified as "quasi-indexers." Q5 (Transient) equals 1 if the firm is ranked in the top quintile of proportional ownership by the group of transient institutions, Q5 (Quasi-indexers) equals 1 if the firm is ranked in the top quintile of proportional ownership by the group of quasi-indexer institutions, and Q5 (Dedicated) equals 1 if the firm is ranked in the top quintile of proportional ownership by the group of dedicated institutions. The other variables are defined in Table 2. Panel B reports the estimated coefficients and standard errors from the probit regression of EPS linking. The standard errors are clustered at the firm level and are robust to heteroskedasticity. ${ }^{*},{ }^{* *}$, and ${ }^{* * *}$ indicate significance at the $10 \%, 5 \%$, and $1 \%$ levels, respectively.

Panel A. EPS-Linking versus Non-EPS-Linking Firms

\begin{tabular}{|c|c|c|c|c|}
\hline Variables & $\begin{array}{c}\frac{\text { EPS-Linking Firms }}{\text { Mean }} \\
\text { (Median) } \\
\end{array}$ & $\begin{array}{c}\text { Non-EPS-Linking Firms } \\
\text { Mean } \\
\text { (Median) } \\
\end{array}$ & $\begin{array}{c}t \text {-Test: } \\
t \text {-Statistic } \\
\text { (p-Value) } \\
\end{array}$ & $\begin{array}{c}\text { Rank Test: } \\
\chi^{2} \\
(p \text {-Value }) \\
\end{array}$ \\
\hline Total assets (\$mil) & $\begin{array}{c}4,864 \\
(1,168) \\
n=6,125\end{array}$ & $\begin{array}{c}3,383 \\
(735) \\
n=3,711\end{array}$ & $\begin{array}{l}3.71 \\
(0.0002)\end{array}$ & $\begin{array}{l}207.80 \\
(<0.0001)\end{array}$ \\
\hline Cash & $\begin{array}{c}0.12 \\
(0.06) \\
n=6,093\end{array}$ & $\begin{array}{c}0.16 \\
(0.08) \\
n=3,684\end{array}$ & $\begin{array}{c}10.41 \\
(<0.0001)\end{array}$ & $\begin{array}{l}51.63 \\
(<0.0001)\end{array}$ \\
\hline Profitability & $\begin{array}{c}0.05 \\
(0.06) \\
n=6,092\end{array}$ & $\begin{array}{c}0.03 \\
(0.05) \\
n=3,685\end{array}$ & $\begin{array}{c}7.76 \\
(<0.0001)\end{array}$ & $\begin{array}{l}119.89 \\
(<0.0001)\end{array}$ \\
\hline Payout ratio & $\begin{array}{c}0.19 \\
(0.06) \\
n=5,784\end{array}$ & $\begin{array}{c}0.16 \\
(0.00) \\
n=3,446\end{array}$ & $\begin{array}{c}5.17 \\
(<0.0001)\end{array}$ & $\begin{array}{l}80.94 \\
(<0.0001)\end{array}$ \\
\hline Industry-adjusted leverage & $\begin{array}{c}0.06 \\
(0.04) \\
n=6,067\end{array}$ & $\begin{array}{c}0.04 \\
(0.02) \\
n=3,681\end{array}$ & $\begin{array}{l}3.62 \\
(0.0003)\end{array}$ & $\begin{array}{l}12.32 \\
(0.0004)\end{array}$ \\
\hline Market to book & $\begin{array}{c}1.92 \\
(1.45) \\
n=6,067\end{array}$ & $\begin{array}{c}1.87 \\
(1.27) \\
n=3,681\end{array}$ & $\begin{array}{c}1.08 \\
(0.28)\end{array}$ & $\begin{array}{c}97.18 \\
(<0.0001)\end{array}$ \\
\hline Abnormal return & $\begin{array}{c}6.83 \% \\
(0.45 \%) \\
n=5,955\end{array}$ & $\begin{array}{c}10.55 \% \\
(-4.68 \%) \\
n=3,609\end{array}$ & $\begin{array}{c}0.98 \\
(0.33)\end{array}$ & $\begin{array}{l}21.47 \\
(<0.0001)\end{array}$ \\
\hline Management options & $\begin{array}{c}0.029 \\
(0.022) \\
n=5,963\end{array}$ & $\begin{array}{c}0.030 \\
(0.022) \\
n=3,582\end{array}$ & $\begin{array}{c}1.91 \\
(0.06)\end{array}$ & $\begin{array}{c}0.00 \\
(0.98)\end{array}$ \\
\hline GIndex & $\begin{array}{c}9.45 \\
(9.00) \\
n=3,475\end{array}$ & $\begin{array}{c}9.02 \\
(9.00) \\
n=1,722\end{array}$ & $\begin{array}{c}5.50 \\
(<0.0001)\end{array}$ & $\begin{array}{c}30.53 \\
(<0.0001)\end{array}$ \\
\hline Institutional holding & $\begin{array}{c}44.23 \% \\
(55.34 \%) \\
n=3,251\end{array}$ & $\begin{array}{c}50.89 \% \\
(59.85 \%) \\
n=1,600\end{array}$ & $\begin{array}{c}6.29 \\
(<0.0001)\end{array}$ & $\begin{array}{l}25.92 \\
(<0.0001)\end{array}$ \\
\hline Q5 (Transient) & $\begin{array}{c}0.39 \\
(0.00) \\
n=3,225\end{array}$ & $\begin{array}{c}0.38 \\
(0.00) \\
n=1,580\end{array}$ & $\begin{array}{c}0.28 \\
(0.78)\end{array}$ & $\begin{array}{c}0.08 \\
(0.78)\end{array}$ \\
\hline Q5 (Quasi-indexers) & $\begin{array}{c}0.78 \\
(1.00) \\
n=3,180\end{array}$ & $\begin{array}{c}0.71 \\
(1.00) \\
n=1,566\end{array}$ & $\begin{array}{c}5.24 \\
(<0.0001)\end{array}$ & $\begin{array}{l}27.31 \\
(<0.0001)\end{array}$ \\
\hline Q5 (Dedicated) & $\begin{array}{c}0.15 \\
(0.00) \\
n=3,236\end{array}$ & $\begin{array}{c}0.15 \\
(0.00) \\
n=1,588\end{array}$ & $\begin{array}{c}0.03 \\
(0.98)\end{array}$ & $\begin{array}{c}0.00 \\
(0.98)\end{array}$ \\
\hline
\end{tabular}


TABLE 4 (continued)

Self-Selection of EPS Linking

\begin{tabular}{|c|c|}
\hline Independent Variables & Bonus Tied to EPS ( 1 if Yes, 0 if No) \\
\hline Glndex & $\begin{array}{l}0.049^{\star \star *} \\
(0.009)\end{array}$ \\
\hline Institutional holding & $\begin{array}{l}-0.244^{* * *} \\
(0.067)\end{array}$ \\
\hline Q5 (Transient) & $\begin{array}{l}0.104^{\star \star} \\
(0.045)\end{array}$ \\
\hline Q5 (Quasi-indexers) & $\begin{array}{l}0.156^{\star \star \star} \\
(0.051)\end{array}$ \\
\hline Q5 (Dedicated) & $\begin{array}{c}-0.042 \\
(0.059)\end{array}$ \\
\hline In(Total assets) & $\begin{array}{l}0.109^{\star \star \star} \\
(0.019)\end{array}$ \\
\hline Cash & $\begin{array}{l}-0.956^{\star * *} \\
(0.170)\end{array}$ \\
\hline Profitability & $\begin{array}{l}1.214^{\star \star \star} \\
(0.272)\end{array}$ \\
\hline Payout ratio & $\begin{array}{c}0.121 \\
(0.092)\end{array}$ \\
\hline Industry-adjusted leverage & $\begin{array}{r}-0.145 \\
(0.163)\end{array}$ \\
\hline Market to book & $\begin{array}{r}0.028^{*} \\
(0.017)\end{array}$ \\
\hline Abnormal return & $\begin{array}{r}-0.020 \\
(0.019)\end{array}$ \\
\hline Management options & $\begin{array}{r}1.813^{*} \\
(1.108)\end{array}$ \\
\hline Intercept & $\begin{array}{r}-0.173 \\
(0.642)\end{array}$ \\
\hline $\begin{array}{l}\text { Year-fixed effects } \\
\text { Industry-fixed effects }\end{array}$ & $\begin{array}{l}\text { Yes } \\
\text { Yes }\end{array}$ \\
\hline Test if Q5 (Transient) = Q5 (Quasi-indexers) & $\begin{array}{c}0.57 \\
(0.45)\end{array}$ \\
\hline Test if Q5 (Transient) $=$ Q5 (Dedicated) & $\begin{array}{l}3.77 \\
(0.05)\end{array}$ \\
\hline Test if Q5 (Quasi-indexers) $=$ Q5 (Dedicated) & $\begin{array}{c}6.93 \\
(0.01)\end{array}$ \\
\hline $\begin{array}{l}\text { No. of obs. } \\
\chi^{2} \\
\text { Prob }>\chi^{2}\end{array}$ & $\begin{array}{c}4,426 \\
681.80 \\
<0.001\end{array}$ \\
\hline
\end{tabular}

Given that EPS-linking firms are different from non-EPS-linking firms, we conduct a probit regression of EPS linking. The probit regression is a part of our procedure in controlling for the self-selection of EPS linking. The estimated coefficients and standard errors are reported in Panel B of Table 4. The probit regression confirms most of the univariate results of Panel A and shows that greater GIndex and smaller institutional holdings increase the probability of linking CEO bonus to EPS. Furthermore, large ownership by institutions that have high or median portfolio turnover increases the probability that the CEO's bonus is tied to EPS. This is consistent with the literature on institutional investor horizon (myopia) and EPS focus.

Now we are ready to conduct the multivariate analysis of repurchasing using the EPS-bonus linking as one of the explanatory variables. We start by estimating 
a Tobit regression of the share buyback ratio on all firms. ${ }^{11}$ But the self-selection of the firms into the different bonus contracts creates a problem: Treating the EPS factor as exogenous would generate biased estimates. To deal with the issue, we use the propensity score matching approach (LaLonde (1986), Doyle, Ge, and McVay (2007), and Francis, Lennox, and Wang (2012)). ${ }^{12}$

We implement the matching procedure as following: First, we estimate the probit model of EPS linking for each sample year, similar to the probit regression reported in Panel B of Table 4, except Table 4 reports the regression on the sample of all years. We then predict the propensity for the firm to link CEO bonus with EPS and we sort the sample by the predicted probabilities (propensity score). For each EPS-linking firm, we find a non-EPS-linking firm with the closest propensity score. Finally, we estimate the models of share repurchasing using the matched-pair sample. This method creates a non-EPS-linking control sample with the same predicted probabilities of linking CEO bonus to EPS as the EPS-linking sample, and thus controls for the self-selection caused by underlying firm characteristics. To assess the effectiveness of the matching between the EPS-linking firms and their non-EPS-linking counterparts, we test the differences between two groups (not tabulated). Eight of the $10 t$-tests and 7 of the 10 rank tests are not statistically significant, indicating that the matching algorithm was successful in achieving balance for most covariates. Moreover, even in the cases in which the means and medians are statistically different, the economic differences between the treatment and control samples are small. Statistical significance appears to occur because we have a relatively large sample size for these tests.

Table 5 presents the main test of our first hypothesis. In the regressions, we control for whether earnings are negative because if the earnings are not positive, a repurchase will not increase EPS. We also control for year- and industry-fixed effects in the estimation. We compute the standard errors by clustering the observations by firm. The standard errors are also robust to heteroskedasticity. ${ }^{13}$ Columns 1 and 2 report the estimated coefficients and standard errors from the Tobit regressions on all firms, and columns 3 and 4 report those from the regressions on the propensity-score-matched samples.

The variable of interest is the indicator for whether EPS is a factor in the CEO's bonus, and its coefficient shows that linking the CEO's bonus to EPS affects the scaled share buyback positively and significantly. Column 1 of Table 5 shows that tying the CEO's bonus to EPS increases the scaled share buyback by $0.5 \%$, which is more than one-third of the sample mean (the sample mean of

\footnotetext{
${ }^{11}$ We also estimate a probit model of whether the net repurchase is positive and report the results (which produce the same inferences) in the Internet Appendix (available at www.jfqa.org).

${ }^{12}$ Another procedure is the standard two-step analysis, with the first step estimating the selfselection of firms into EPS linking and the second step conducting Tobit and probit regressions of share repurchasing. We use the two-step selection model and find that EPS linking has a positive and significant impact on both the buyback ratio and the probability of buyback (not tabulated).

${ }^{13}$ Petersen (2009) compares different approaches in estimating standard errors using financial panel data. He finds that in the presence of both firm and time effects, clustering by firms after including time dummies yields unbiased estimates of standard errors. Another way is to estimate two-way (firm and year) cluster-robust standard errors, but not include year dummies. We repeat our analysis by adopting such an approach and find that the results are similar.
} 
TABLE 5

\section{Multivariate Analysis of Share Buyback and Tying CEO Bonus to EPS}

In Table 5, we report the estimated coefficients and standard errors obtained from the Tobit regression of scaled net repurchase. EPSfactor equals 1 if earnings per share (EPS) is a factor in chief executive officer (CEO) bonus, and 0 otherwise. Below_EPS_Growth equals 1 if $E_{0}<E_{-1} \times(1+g)$ (current-period earnings are less than last-period earnings multiplied by the expected growth rate), and 0 otherwise. The expected growth rate is proxied by the EPS growth rate from years $t-2$ to $t-1$. ESO_EX is employee options exercised during the year/shares outstanding as of the end of last year. The remaining variables are defined in Table 2 . The numbers in parentheses are standard errors. The standard errors are clustered at the firm level and are robust to heteroskedasticity. Columns 1 and 2 are the Tobit regressions on all firms; columns 3 and 4 are the Tobit regressions on the matched-pair sample. We implement the matching procedure as follows: First, we estimate the probit model of EPS linking (Panel B of Table 4) for each year. We then predict the propensity for the firm to link CEO bonus to EPS and we sort the sample by the predicted probabilities (propensity score). For each EPS-linking firm, we find a non-EPS-linking firm with the closest propensity score. Finally, we estimate the Tobit models of share repurchasing using the matched-pair sample. The standard errors are clustered at the firm level and are robust to heteroskedasticity. ${ }^{*},{ }^{* *}$, and ${ }^{* * *}$ indicate significance at the $10 \%, 5 \%$, and $1 \%$ levels, respectively.

Net Repurchase Scaled by Market Value of Equity

\begin{tabular}{|c|c|c|c|c|}
\hline \multirow[b]{2}{*}{ Variables } & \multicolumn{2}{|c|}{ All Firms } & \multicolumn{2}{|c|}{ Matched-Pair Sample } \\
\hline & 1 & 2 & 3 & 4 \\
\hline EPSfactor & $\begin{array}{l}0.005^{\star \star \star} \\
(0.001)\end{array}$ & $\begin{array}{l}0.004^{\star \star} \\
(0.002)\end{array}$ & $\begin{array}{l}0.007^{* \star *} \\
(0.001)\end{array}$ & $\begin{array}{l}0.005^{* *} \\
(0.002)\end{array}$ \\
\hline Below_EPS_Growth & $\begin{array}{l}0.003^{\star \star \star} \\
(0.001)\end{array}$ & $\begin{array}{l}0.005^{\star \star} \\
(0.002)\end{array}$ & $\begin{array}{l}0.003^{\star * *} \\
(0.001)\end{array}$ & $\begin{array}{l}0.008^{* * *} \\
(0.002)\end{array}$ \\
\hline ESO_EX & - & $\begin{array}{c}0.123^{\star} \\
(0.068)\end{array}$ & - & $\begin{array}{l}0.050^{\star \star} \\
(0.024)\end{array}$ \\
\hline In(Total assets) & $\begin{array}{l}0.006^{\star \star \star} \\
(0.001)\end{array}$ & $\begin{array}{c}0.009^{\star \star \star *} \\
(<0.001)\end{array}$ & $\begin{array}{l}0.005^{\star * *} \\
(0.001)\end{array}$ & $\begin{array}{c}0.001 \\
(0.001)\end{array}$ \\
\hline Profitability & $\begin{array}{l}0.121^{\star \star \star} \\
(0.009)\end{array}$ & $\begin{array}{l}0.136^{\star \star \star} \\
(0.018)\end{array}$ & $\begin{array}{l}0.144^{\star \star *} \\
(0.011)\end{array}$ & $\begin{array}{l}0.051^{\star *} \\
(0.023)\end{array}$ \\
\hline Cash & $\begin{array}{l}0.041^{\star \star \star} \\
(0.005)\end{array}$ & $\begin{array}{l}0.045^{\star \star \star} \\
(0.008)\end{array}$ & $\begin{array}{l}0.040^{* * *} \\
(0.006)\end{array}$ & $\begin{array}{l}0.099 * * * \\
(0.011)\end{array}$ \\
\hline Payout ratio & $\begin{array}{c}-0.004 \\
(0.003)\end{array}$ & $\begin{array}{c}-0.011^{\star \star} \\
(0.005)\end{array}$ & $\begin{array}{c}-0.010^{\star \star} \\
(0.003)\end{array}$ & $\begin{array}{c}-0.016^{\star \star} \\
(0.005)\end{array}$ \\
\hline Industry-adjusted leverage & $\begin{array}{c}-0.007 \\
(0.005)\end{array}$ & $\begin{array}{c}-0.001 \\
(0.008)\end{array}$ & $\begin{array}{r}-0.009^{\star} \\
(0.005)\end{array}$ & $\begin{array}{c}0.014 \\
(0.008)\end{array}$ \\
\hline Takeover & $\begin{array}{c}0.001 \\
(0.005)\end{array}$ & $\begin{array}{c}0.002 \\
(0.005)\end{array}$ & $\begin{array}{l}0.036^{\star \star \star} \\
(0.005)\end{array}$ & $\begin{array}{l}0.015^{* * *} \\
(0.005)\end{array}$ \\
\hline Market to book & $\begin{array}{c}-0.004^{\star \star \star} \\
(0.001)\end{array}$ & $\begin{array}{c}-0.001 \\
(0.001)\end{array}$ & $\begin{array}{c}-0.003^{\star \star \star} \\
(0.001)\end{array}$ & $\begin{array}{c}-0.005^{\star \star \star} \\
(0.001)\end{array}$ \\
\hline Abnormal return & $\begin{array}{c}-0.003^{\star \star \star} \\
(0.001)\end{array}$ & $\begin{array}{c}-0.006^{\star \star \star} \\
(0.002)\end{array}$ & $\begin{array}{r}-0.002^{\star} \\
(0.001)\end{array}$ & $\begin{array}{c}-0.002 \\
(0.003)\end{array}$ \\
\hline Management options & $\begin{array}{l}0.226^{\star \star \star} \\
(0.029)\end{array}$ & $\begin{array}{l}0.207^{\star * *} \\
(0.053)\end{array}$ & $\begin{array}{l}0.276^{* * *} \\
(0.034)\end{array}$ & $\begin{array}{l}0.279^{* \star *} \\
(0.062)\end{array}$ \\
\hline Earnings are negative & $\begin{array}{c}-0.015^{\star \star \star} \\
(0.002)\end{array}$ & $\begin{array}{c}-0.017^{\star \star \star} \\
(0.004)\end{array}$ & $\begin{array}{c}-0.019^{\star \star \star} \\
(0.002)\end{array}$ & 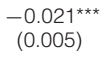 \\
\hline Intercept & $\begin{array}{c}-0.096^{\star \star *} \\
(0.017)\end{array}$ & $\begin{array}{c}-0.075^{\star \star \star} \\
(0.029)\end{array}$ & $\begin{array}{c}-0.070^{\star \star \star} \\
(0.020)\end{array}$ & $\begin{array}{c}-0.193^{\text {** }} \\
(0.018)\end{array}$ \\
\hline $\begin{array}{l}\text { Year-fixed effects } \\
\text { Industry-fixed effects }\end{array}$ & $\begin{array}{l}\text { Yes } \\
\text { Yes }\end{array}$ & $\begin{array}{l}\text { Yes } \\
\text { Yes }\end{array}$ & $\begin{array}{l}\text { Yes } \\
\text { Yes }\end{array}$ & $\begin{array}{l}\text { Yes } \\
\text { Yes }\end{array}$ \\
\hline $\begin{array}{l}\text { No. of obs. } \\
\chi^{2} \\
\text { Prob }>\chi^{2}\end{array}$ & $\begin{aligned} & 7,612 \\
& 1,212.42 \\
&< 0.001\end{aligned}$ & $\begin{array}{c}2,459 \\
555.37 \\
<0.001\end{array}$ & $\begin{aligned} & 5,522 \\
& 1,179.61 \\
< & 0.001\end{aligned}$ & $\begin{aligned} & 2,126 \\
& 736.28 \\
< & 0.001\end{aligned}$ \\
\hline
\end{tabular}

scaled buyback is $1.42 \%$, as shown in Table 2). ${ }^{14}$ The control variables are consistent with extant work, and as expected, when earnings are not positive, firms tend to buy back fewer shares. Columns 3 and 4 confirm what we have observed

\footnotetext{
${ }^{14}$ There has recently been increased interest in ASR programs. We check that our results are not driven by ASRs. ASRs were extremely rare before 2004, and even from 2004 to 2007, the dollar amount of ASRs was only about $20 \%$ of the dollar amount of OMRs. For firms that conducted ASRs during 2004-2007, we deleted the amount of ASRs from the total amount of repurchasing and repeated the main analysis; our results do not change. Finally, we repeated the main analysis for the subset of firms before 2004 (when ASRs were rare) and our results do not change.
} 
from columns 1 and 2: Controlling for other firm characteristics, firms tend to repurchase more when their CEO's bonus is tied to EPS. This evidence supports Hypothesis 1: Controlling for other determinants of repurchases and self-selection into EPS linking, EPS-based bonus structures increase repurchases.

Below_EPS_Growth is positive and significant, showing that firms tend to buy back more when their earnings growth is below the expected EPS growth rate. This is consistent with the findings by Bens et al. (2003). ESO EX (employee options exercised during the year/shares outstanding as of the end of last year) is positive and significant as well. The effect of tying the CEO's bonus to EPS remains positive and significant, showing that it is significant and incremental to the market-driven motives established in the literature. The effect of EPS-bonus linking is comparable to that of market-driven motives: We test whether the coefficients of EPSfactor and Below_EPS_Growth are different from each other. For column 1 of Table 5, the $F$-statistic is 0.81 with a $p$-value of 0.37 (i.e., the two coefficients are similar in magnitude). This similarity holds in all of the relevant regressions.

We use the results of an analogous probit model (in Table 2 of the Internet Appendix) to compare the economic effect of bonuses with that of management options. Holding other predictor variables at their means, the predicted probability of buyback is 0.522 when EPS is not a factor in bonus decisions, and is 0.593 when EPS is a factor in the bonus award. Holding other variables at their means, the predicted probability of buyback is 0.515 when "management options" is at the 10th percentile $(0.0047)$, and is 0.614 when "management options" is at the 90th percentile (0.0554). These numbers suggest that the impact of linking CEO bonus to EPS is comparable to that of management options. Thus, whether we use the propensity to repurchase or the amount repurchased, EPS-linked bonus plans increase repurchasing in an economically meaningful way.

\section{B. Share Repurchases and the Threshold EPS}

The results in Table 5 show that, controlling for self-selection, linking a CEO's bonus to EPS significantly increases repurchases. An even more compelling result would be to isolate the effect right around the bonus threshold (the second part of our first hypothesis). A subsample of firms disclose the bonus threshold, so in this section we test whether firms are more likely to conduct share repurchases when their EPS is right below the level that triggers the bonus. To do this, we need to estimate what each repurchasing firm's EPS would have been without the repurchases, that is, the AS-IF EPS. We compute AS-IF_EPS as follows:

$$
A S-I F \_E P S=\frac{\text { Earnings }_{t}+0.5 \times \text { Cost }_{t}}{\text { Weighted average shares outstanding }}+0.5 \times \text { Shares bought }_{t}+.
$$

Earnings $_{t}$ is the reported income available to common shareholders in year $t$. Weighted average shares outstanding $g_{t}$ is the number of shares outstanding used to compute the EPS reported by the company, as provided by Compustat. Shares bought $_{t}$ is the number of shares bought during the fiscal year, computed as the dollar amount of net repurchase divided by the monthly average stock price. Cost $t_{t}$ is the "opportunity cost," that is, what the company could have earned 
otherwise from the money it spends on share repurchases, estimated as the product of the buyback dollar amount and the annualized 3-month Treasury-bill rate, as in Hribar et al. (2006). We scale Cost $_{t}$ by 0.5 in the numerator and Shares bought $_{t}$ by 0.5 in the denominator, because we assume that the shares are bought back uniformly over the year.

We include nonrepurchasing firms in the analysis. For the nonrepurchasing firms, $A S-I F \_E P S$ is the same as the reported EPS. The majority of firm-year observations use basic EPS, but some use diluted EPS as the threshold EPS for CEO bonus. We compute $A S-I F \_E P S$ accordingly, to compare them with the threshold EPS consistently. ${ }^{15}$ If $A S$-IF EPS is less than but within $15 \%$ of the threshold EPS, we say that $A S-I F \_E P S$ is right below the threshold. We also use $10 \%$ and $20 \%$ as the cutoffs, and the results are qualitatively the same.

In Table 6, we compare the frequency, dollar amount, and relative size of share buyback between firms with $A S-I F \_E P S$ right below the threshold EPS and other firms. When AS-IF_EPS is right below the threshold EPS, 75\% of the observations conduct a share buyback, significantly higher than the $60 \%$ otherwise. The amount of buyback and the buyback ratio are significantly higher when $A S-I F_{-} E P S$ is right below the threshold EPS. The difference in the medians is statistically significant, although the statistical difference in means between the two subsets is a little weaker. To give a sense of the magnitudes involved, we examine average bonuses and repurchase amounts. In the sample of repurchasing firms whose $A S-I F \_E P S$ is below the threshold EPS for bonus but the reported EPS is above the threshold EPS, the average CEO whose repurchase allowed him

TABLE 6

Share Buyback and Being Right below Threshold EPS

In Table 6, we examine AS-IF_EPS to measure what earnings per share (EPS) would have been without the repurchase. For the repurchasing firms, we compute what EPS would have been without the repurchase, that is, the AS-IF_EPS, as follows:

$$
\text { AS-IF_EPS }=\frac{\text { Earnings }_{t}+0.5 \times \text { Cost }_{t}}{\text { Weighted average shares outstanding } t+0.5 \times \text { Shares bought }_{t}} .
$$

If AS-IF_EPS is less than the threshold but within $15 \%$ of the threshold EPS, we say it is right below the threshold EPS. $n$ is the number of observations.

\begin{tabular}{|c|c|c|c|c|}
\hline \multirow[b]{2}{*}{ Cases } & \multirow[b]{2}{*}{$n$} & \multirow{2}{*}{$\begin{array}{c}\text { Frequency } \\
\text { of Share } \\
\text { Repurchases }\end{array}$} & \multirow{2}{*}{$\begin{array}{c}\begin{array}{c}\text { Amount of } \\
\text { Buyback } \\
(\$ \text { mil })\end{array} \\
\begin{array}{c}\text { Mean } \\
\text { (Median) }\end{array} \\
\end{array}$} & $\begin{array}{l}\text { Net Repurchases Scaled by } \\
\text { Market Value of Equity (\%) } \\
\end{array}$ \\
\hline & & & & $\begin{array}{c}\text { Mean } \\
\text { (Median) }\end{array}$ \\
\hline $\begin{array}{l}\text { AS-IF_EPS is right below the } \\
\text { threshold EPS }\end{array}$ & 130 & $75 \%$ & $\begin{array}{l}349.99 \\
(28.88)\end{array}$ & $\begin{array}{c}3.01 \\
(1.75)\end{array}$ \\
\hline $\begin{array}{l}\text { AS-IF_EPS is not right below the } \\
\text { threshold EPS }\end{array}$ & 273 & $60 \%$ & $\begin{array}{r}127.38 \\
(3.00)\end{array}$ & $\begin{array}{l}2.39 \\
(0.41)\end{array}$ \\
\hline $\begin{array}{l}\text { t-test: } t \text {-statistic } \\
\text { (p-value) }\end{array}$ & & $\begin{array}{l}2.81 \\
(0.005)\end{array}$ & $\begin{array}{l}2.75 \\
(0.007)\end{array}$ & $\begin{array}{l}1.55 \\
(0.12)\end{array}$ \\
\hline $\begin{array}{l}\text { Kruskal-Wallis test: } \chi^{2} \\
\text { ( } p \text {-value) }\end{array}$ & & $\begin{array}{l}7.76 \\
(0.005)\end{array}$ & $\begin{array}{l}9.16 \\
(0.003)\end{array}$ & $\begin{array}{l}6.67 \\
(0.01)\end{array}$ \\
\hline
\end{tabular}

\footnotetext{
${ }^{15}$ For basic EPS, Compustat provides earnings (item 237) and weighted average shares outstanding (item 54), which are used to calculate basic EPS. For diluted EPS, Compustat provides weighted average shares outstanding (item 171), which are used to calculate diluted EPS (item 57). We compute earnings as the product of item 171 and item 57.
} 
to claim his bonus would have lost $\$ 1.14$ million in bonus if EPS had fallen below the threshold. Comparing it with the amount repurchased, we find that the average ratio of bonus to repurchase amount is $7.8 \%$ (median of $1 \%$ ).

In the multivariate analysis, we estimate the Tobit model of buyback ratio, incorporating the indicator of whether the AS-IF_EPS is close to but below the threshold EPS. The estimated coefficients and standard errors from the regression are presented in Table 7. Column 1 includes all firms, and columns 2 and 3 include

\section{TABLE 7}

\section{Multivariate Analysis of Share Buyback and Being Right below Threshold EPS}

In Table 7, we present the estimated coefficients and standard errors obtained from the Tobit regressions of scaled net repurchase. Right-below equals 1 when AS-IF_EPS is within 15\% below the EPS threshold, and 0 otherwise Below_EPS_Growth equals 1 if $E_{0}<E_{-1} \times(1+g)$ (current-period earnings are less than last-period earnings multiplied by the expected growth rate), and 0 otherwise. The expected growth rate is proxied by the earnings per share (EPS) growth rate from years $t-2$ to $t-1$. ESO_EX is employee options exercised during the year/shares outstanding as of the end of last year. The remaining variables are defined in Table 2. Column 1 considers firms whose AS-IF_EPS is below the threshold EPS but within $15 \%$ of the threshold and all other firms. Columns 2 and 3 consider firms whose AS-IF_EPS is below the threshold EPS but within $15 \%$ of the threshold and firms whose AS-IF_EPS is above the threshold EPS but within $15 \%$ of the threshold. We compute AS-IF_EPS as follows:

$$
\text { AS-IF_EPS }=\frac{\text { Earnings } t+0.5 \times \text { Cost }_{t}}{\text { Weighted average shares outstanding } t+0.5 \times \text { Shares bought }_{t}} \text {. }
$$

Right-below is 1 if the AS-IF_EPS is less than but within $15 \%$ of the threshold earnings per share, and 0 otherwise. SIC is Standard Industrial Classification. The numbers in parentheses are standard errors. The standard errors are clustered at the firm level and are robust to heteroskedasticity. ${ }^{*},{ }^{\star *}$, and ${ }^{* * *}$ indicate significance at the $10 \%, 5 \%$, and $1 \%$ levels respectively.

\begin{tabular}{|c|c|c|c|}
\hline \multirow[b]{2}{*}{ Variables } & \multicolumn{3}{|c|}{ Net Repurchase Scaled by Market Value of Equity } \\
\hline & 1 & 2 & 3 \\
\hline Right-below & $\begin{array}{l}0.013^{\star *} \\
(0.005)\end{array}$ & $\begin{array}{l}0.024^{* \star \star} \\
(0.006)\end{array}$ & $\begin{array}{c}0.015^{*} \\
(0.008)\end{array}$ \\
\hline Below_EPS_Growth & - & - & $\begin{array}{c}-0.004 \\
(0.008)\end{array}$ \\
\hline ESO_EX & - & - & $\begin{array}{c}0.138 \\
(0.433)\end{array}$ \\
\hline In(Total assets) & $\begin{array}{l}0.007^{\star \star \star} \\
(0.002)\end{array}$ & $\begin{array}{l}0.010^{\star \star \star} \\
(0.002)\end{array}$ & $\begin{array}{l}0.010^{\star \star \star} \\
(0.003)\end{array}$ \\
\hline Profitability & $\begin{array}{l}0.331^{\star \star \star} \\
(0.062)\end{array}$ & $\begin{array}{l}0.306^{\star \star \star *} \\
(0.095)\end{array}$ & $\begin{array}{l}0.274^{* *} \\
(0.123)\end{array}$ \\
\hline Cash & $\begin{array}{c}0.044 \\
(0.024)\end{array}$ & $\begin{array}{c}0.034 \\
(0.028)\end{array}$ & $\begin{array}{l}0.083^{\star *} \\
(0.033)\end{array}$ \\
\hline Payout & $\begin{array}{r}-0.007 \\
(0.006)\end{array}$ & $\begin{array}{r}-0.007 \\
(0.011)\end{array}$ & $\begin{array}{c}-0.056^{\star * *} \\
(0.019)\end{array}$ \\
\hline Industry-adjusted leverage & $\begin{array}{r}-0.005 \\
(0.018)\end{array}$ & $\begin{array}{c}0.005 \\
(0.023)\end{array}$ & $\begin{array}{c}-0.015 \\
(0.023)\end{array}$ \\
\hline Takeover & $\begin{array}{c}-0.021 \\
(0.019)\end{array}$ & $\begin{array}{r}-0.019 \\
(0.030)\end{array}$ & $\begin{array}{r}-0.053 \\
(0.039)\end{array}$ \\
\hline Market to book & $\begin{array}{c}-0.008^{\star \star \star} \\
(0.002)\end{array}$ & $\begin{array}{r}-0.005 \\
(0.004)\end{array}$ & $\begin{array}{r}-0.009^{*} \\
(0.005)\end{array}$ \\
\hline Abnormal return & $\begin{array}{c}-0.009 \\
(0.007)\end{array}$ & $\begin{array}{r}-0.008 \\
(0.012)\end{array}$ & $\begin{array}{c}-0.036^{* *} \\
(0.016)\end{array}$ \\
\hline Management options & 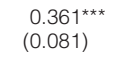 & $\begin{array}{l}0.589^{* \star *} \\
(0.127)\end{array}$ & $\begin{array}{c}0.232 \\
(0.183)\end{array}$ \\
\hline Earnings are negative & $\begin{array}{c}-0.013 \\
(0.012)\end{array}$ & $\begin{array}{r}-0.020 \\
(0.027)\end{array}$ & $\begin{array}{r}-0.226 \\
(0.136)\end{array}$ \\
\hline Intercept & $\begin{array}{c}-0.087^{\star \star \star} \\
(0.022)\end{array}$ & $\begin{array}{r}-0.040 \\
(0.054)\end{array}$ & $\begin{array}{c}0.011 \\
(0.056)\end{array}$ \\
\hline $\begin{array}{l}\text { Year-fixed effects } \\
\text { Industry-fixed effects (1-digit SIC code) } \\
\text { Only within } 15 \% \text { on either side of threshold }\end{array}$ & $\begin{array}{l}\text { Yes } \\
\text { Yes } \\
\text { No }\end{array}$ & $\begin{array}{l}\text { Yes } \\
\text { Yes } \\
\text { Yes }\end{array}$ & $\begin{array}{l}\text { Yes } \\
\text { Yes } \\
\text { Yes }\end{array}$ \\
\hline $\begin{array}{l}\text { No. of obs. } \\
\chi^{2} \\
\text { Prob }>\chi^{2}\end{array}$ & $\begin{array}{l}385 \\
133.05 \\
<0.001\end{array}$ & $\begin{array}{l}191 \\
127.16 \\
<0.001\end{array}$ & $\begin{array}{l}131 \\
76.99 \\
<0.001\end{array}$ \\
\hline
\end{tabular}


only firms whose $A S-I F \_E P S$ is right below or above the EPS bonus threshold (within 15\%). Firm size and profitability are positive and significant determinants. When $A S-I F \_E P S$ is right below the threshold EPS, the buyback ratio increases by $1.3 \%$ of the market equity (column 1). Thus, Tables 6 and 7 provide further support for Hypothesis 1 in the most compelling setting: when the repurchase would mean the difference between getting a bonus and not getting a bonus.

\section{Gains to CEOs from Share Repurchase}

Having established that firms repurchase more when their CEOs are motivated to manipulate EPS for bonuses, we now confirm that the CEOs gain a financial reward for doing so.

\section{Relation between Bonus Awards and Repurchases}

We estimate a model to predict a CEO's bonus and estimate it over the sample of firms with a bonus plan for which we can determine whether the bonus is tied to EPS.

In the ordinary least squares (OLS) regressions of CEOs' bonus, we have the following specification:

$$
\begin{gathered}
\text { CEOBonus }_{i, t}=\lambda_{0}+\lambda_{1} \text { EPSfactor }_{i, t}+\lambda_{2} \text { EPSfactor }_{i, t} \times \text { Buyback }_{i, t} \\
+\lambda_{3} \text { Buyback }_{i, t}+\lambda_{4} \text { Size }_{i, t}+\lambda_{5} \text { Ret }_{i, t}+\lambda_{6} \text { Profitability }_{i, t}+\delta_{i, t} .
\end{gathered}
$$

CEOBonus is measured two ways: the natural $\log$ of $(1+$ bonus $)$ and the ratio of bonus to (bonus + salary). Size is the natural log of the total assets, and Ret is the 1-year return to shareholders. Buyback is measured in three ways: whether the net repurchase is positive, $\log$ of $(1+$ net repurchase $)$, and net repurchase scaled by market value of equity. EPSfactor is 1 if the CEO's bonus is directly tied to EPS, and 0 otherwise. Equation (1) includes the interaction term between EPSfactor and the buyback measure. For firms whose CEO's bonus is not tied to EPS, $\lambda_{3}$ measures the impact of a buyback on CEO bonus. For firms whose CEO's bonus is tied to EPS, $\lambda_{2}+\lambda_{3}$ captures the impact of a buyback on CEO bonus. We also control for firm profit and year- and industry-fixed effects in the estimation of equation (1).

The results in Table 8 show that larger firms award a larger bonus to their CEOs than smaller firms do. Higher stock return and greater profit are associated with a greater bonus, consistent with the positive pay-performance relation documented in the literature. None of the three buyback measures has a significant coefficient on the level of bonus (i.e., $\lambda_{3}$ is not statistically different from $0)$. Thus, buyback alone, when the CEO's bonus is not tied to EPS, is not related to the level of the bonus. However, the interaction term between the indicator of CEO bonus being tied to EPS and the buyback measure is positive and significant. $F$-tests reported at the bottom of the table confirm that $\lambda_{2}+\lambda_{3}$ is positive and significant in columns 1-3. Thus, when CEO bonus is tied to EPS, share repurchasing increases the level of CEO bonus. The lack of significance for buyback alone helps mitigate concerns about endogeneity, whereby bonuses and buybacks would be associated because of their potential mutual association with performance. 
TABLE 8

OLS Regressions of CEO Bonus

Table 8 presents estimated coefficients and standard errors from the ordinary least squares (OLS) regression of chief executive officer (CEO) bonus according to the following model:

$$
\begin{aligned}
\text { CEOBonus }_{i, t}= & \lambda_{0}+\lambda_{1} \text { EPSfactor }_{i, t}+\lambda_{2} \text { EPSfactor }_{i, t} \times \text { Buyback }_{i, t} \\
& +\lambda_{3} \text { Buyback }_{i, t}+\lambda_{4} \text { Size }_{i, t}+\lambda_{5} \text { Ret }_{i, t}+\lambda_{6} \text { Profitability }_{i, t}+\delta_{i, t} .
\end{aligned}
$$

EPSfactor equals 1 if earnings per share (EPS) is a factor in CEO bonus, and 0 otherwise. Columns $1-3$ examine the natural log of bonus, and columns 4-6 examine the ratio of bonus to the sum of bonus and salary. The remaining variables are defined in Table 2. The numbers in parentheses are standard errors. The standard errors are clustered at the firm level and are robust to heteroskedasticity. *, ${ }^{* *}$, and ${ }^{* \star *}$ indicate significance at the $10 \%, 5 \%$, and $1 \%$ levels,

\begin{tabular}{|c|c|c|c|c|c|c|}
\hline & 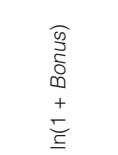 & 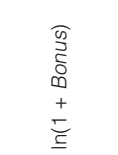 & 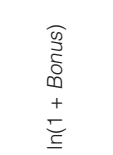 & 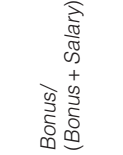 & 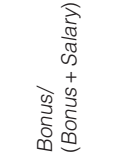 & 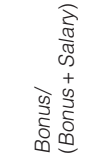 \\
\hline Variables & 1 & 2 & 3 & 4 & 5 & 6 \\
\hline EPSfactor & $\begin{array}{c}0.109 \\
(0.091)\end{array}$ & $\begin{array}{c}0.102 \\
(0.085)\end{array}$ & $\begin{array}{r}0.154^{*} \\
(0.079)\end{array}$ & $\begin{array}{c}0.010 \\
(0.008)\end{array}$ & $\begin{array}{c}0.008 \\
(0.008)\end{array}$ & $\begin{array}{l}0.012^{\star \star} \\
(0.005)\end{array}$ \\
\hline EPSfactor $\times$ Buyback & $\begin{array}{l}0.266^{* *} \\
(0.129)\end{array}$ & $\begin{array}{l}0.095^{\star * *} \\
(0.032)\end{array}$ & $\begin{array}{l}6.326^{\star \star \star} \\
(2.100)\end{array}$ & $\begin{array}{l}0.018^{* *} \\
(0.009)\end{array}$ & $\begin{array}{l}0.008^{* * *} \\
(0.003)\end{array}$ & $\begin{array}{l}0.512^{\text {** }} \\
(0.157)\end{array}$ \\
\hline $\begin{array}{l}\text { Net repurchase is } \\
\text { positive }\end{array}$ & $\begin{array}{c}0.029 \\
(0.100)\end{array}$ & - & - & $\begin{array}{l}0.006 \\
(0.009)\end{array}$ & - & - \\
\hline In(1 + net repurchase $)$ & - & $\begin{array}{c}-0.028 \\
(0.029)\end{array}$ & - & - & $\begin{array}{r}-0.001 \\
(0.003)\end{array}$ & - \\
\hline $\begin{array}{l}\text { Repurchase scaled } \\
\text { by market value of equity }\end{array}$ & - & - & $\begin{array}{c}-2.994 \\
(1.808)\end{array}$ & - & - & $\begin{array}{r}-0.219 \\
(0.130)\end{array}$ \\
\hline In(Total assets) & $\begin{array}{l}0.509^{* * *} \\
(0.025)\end{array}$ & $\begin{array}{l}0.496^{\star \star \star} \\
(0.027)\end{array}$ & $\begin{array}{l}0.516^{\star \star \star} \\
(0.025)\end{array}$ & $\begin{array}{l}0.045^{\star \star \star} \\
(0.002)\end{array}$ & $\begin{array}{l}0.043^{\star \star \star} \\
(0.002)\end{array}$ & $\begin{array}{l}0.046^{\star \star \star} \\
(0.002)\end{array}$ \\
\hline $\begin{array}{l}\text { 1-year return to } \\
\text { shareholders }\end{array}$ & $\begin{array}{l}1.154^{* * *} \\
(0.051)\end{array}$ & $\begin{array}{l}1.145^{\star * *} \\
(0.051)\end{array}$ & $\begin{array}{l}1.136^{\star \star *} \\
(0.051)\end{array}$ & $\begin{array}{l}0.115^{\text {***}} \\
(0.005)\end{array}$ & $\begin{array}{l}0.115^{\star * *} \\
(0.005)\end{array}$ & $\begin{array}{l}0.114^{\star \star \star} \\
(0.005)\end{array}$ \\
\hline Profitability & $\begin{array}{l}1.987^{* * *} \\
(0.429)\end{array}$ & $\begin{array}{l}2.003^{\star \star \star} \\
(0.432)\end{array}$ & $\begin{array}{l}2.044^{\star \star \star} \\
(0.437)\end{array}$ & $\begin{array}{l}0.179^{* \star *} \\
(0.041)\end{array}$ & $\begin{array}{l}0.178^{* * *} \\
(0.041)\end{array}$ & $\begin{array}{l}0.184^{\star \star \star} \\
(0.040)\end{array}$ \\
\hline Intercept & $\begin{array}{r}-1.058^{*} \\
(0.572)\end{array}$ & $\begin{array}{c}-0.945 \\
(0.577)\end{array}$ & $\begin{array}{r}-1.102^{\star} \\
(0.577)\end{array}$ & $\begin{array}{l}-0.167^{\star \star \star} \\
(0.043)\end{array}$ & $\begin{array}{l}-0.151^{\star \star \star} \\
(0.043)\end{array}$ & $\begin{array}{l}-0.169^{\star \star \star} \\
(0.044)\end{array}$ \\
\hline $\begin{array}{l}\text { Year-fixed effects } \\
\text { Industry-fixed effects }\end{array}$ & $\begin{array}{l}\text { Yes } \\
\text { Yes }\end{array}$ & $\begin{array}{l}\text { Yes } \\
\text { Yes }\end{array}$ & $\begin{array}{l}\text { Yes } \\
\text { Yes }\end{array}$ & $\begin{array}{l}\text { Yes } \\
\text { Yes }\end{array}$ & $\begin{array}{l}\text { Yes } \\
\text { Yes }\end{array}$ & $\begin{array}{l}\text { Yes } \\
\text { Yes }\end{array}$ \\
\hline $\begin{array}{l}\text { No. of obs. } \\
R^{2}\end{array}$ & $\begin{array}{l}9,604 \\
0.32\end{array}$ & $\begin{array}{l}9,604 \\
0.32\end{array}$ & $\begin{array}{l}9,604 \\
0.32\end{array}$ & $\begin{array}{l}9,604 \\
0.32\end{array}$ & $\begin{array}{l}9,604 \\
0.32\end{array}$ & $\begin{array}{l}9,604 \\
0.32\end{array}$ \\
\hline $\begin{array}{l}\text { Test if } \lambda_{2}+\lambda_{3}=0 \\
F \text {-statistic ( } p \text {-value })\end{array}$ & $\begin{array}{l}15.05 \\
(<0.001)\end{array}$ & $\begin{array}{c}14.76 \\
(<0.001)\end{array}$ & $\begin{array}{l}8.33 \\
(0.004)\end{array}$ & $\begin{array}{c}12.62 \\
(<0.001)\end{array}$ & $\begin{array}{c}18.76 \\
(<0.001)\end{array}$ & $\begin{array}{l}9.41 \\
(0.002)\end{array}$ \\
\hline
\end{tabular}
respectively.

Instead, the evidence supports Hypothesis 2: When the CEO's bonus is tied to EPS, repurchases increase his bonus award.

The impact of share buyback on the level of bonus is economically significant when CEO bonus is tied to EPS: In column 1 of Table $8, \lambda_{2}+\lambda_{3}$ equals 0.295 , which means that conducting share buyback increases the level of bonus by approximately $34 \%$ (i.e., $\exp (0.295)-1$ ) when CEO bonus is tied to EPS; in column $2, \lambda_{2}+\lambda_{3}$ equals 0.067 , suggesting that an increase of 1 standard deviation in the log of buyback amount (the standard deviation is 2.15) increases the level of bonus by about $14 \%$ when CEO bonus is tied to EPS; in column 3, $\lambda_{2}+\lambda_{3}$ equals 3.33 , meaning that an increase of 1 standard deviation in the scaled buyback (the standard deviation is 0.03 ) increases the level of bonus by about $10 \%$ when CEO bonus is tied to EPS. The analysis of the ratio of bonus to the sum of salary and bonus generates similar results (columns 4-6). In the Internet 
Appendix, an analogous probit model of whether a CEO receives a bonus shows that a share buyback increases the probability of CEO being awarded a bonus, but only when his bonus is tied to EPS.

\section{Robustness of the Bonus Effect to the Endogeneity of Repurchasing}

In the OLS regression of CEO bonus, we use share repurchases as one of the independent variables. However, share buyback is an endogenous choice. As we show in Table 2, repurchasing and nonrepurchasing firms are different along a number of dimensions, in addition to firm size and stock return. We use propensity score matching to control for the differences between nonrepurchasing firms and firms with positive net repurchases: We estimate a probit model of whether a firm has positive net repurchases, generate propensity scores based on the probit estimation, and then, for each firm with positive net repurchase, choose a nonrepurchasing matching firm in the same industry and fiscal year with the closest propensity score.

Table 9 summarizes the mean and median bonus received by CEOs in firms with positive net repurchases versus their propensity-score-matching nonrepurchasing firms. We differentiate the group of firms with CEO bonus tied to EPS from the group of firms whose CEO bonus is not tied to EPS. We find that, within the former group, firms with positive net repurchases grant a greater bonus to their CEOs than their matches. However, for the repurchasing firms whose CEO bonus is not tied to EPS, their CEOs do not receive more bonus than CEOs in the propensity-score-matched firms.

TABLE 9

CEO Bonus in Firms with Positive Net Repurchase and Their Propensity-Score-Matched Nonrepurchasing Firms

In Table 9, we compare the bonus (\$thousand) of chief executive officers (CEOs) in firms with positive net repurchase with their propensity-score-matched nonrepurchasing firms. We estimate a probit model of whether a firm has positive net repurchase, generate propensity scores based on the probit estimation, and then, for each firm with positive net repurchase, choose a nonrepurchasing matching firm in the same industry and fiscal year with the closest propensity score.

\begin{tabular}{|c|c|c|c|c|c|}
\hline Cases & $n$ & $\begin{array}{c}\text { Firms with } \\
\text { Positive Net } \\
\text { Repurchase } \\
\begin{array}{c}\text { Mean } \\
\text { (Median) }\end{array}\end{array}$ & $\begin{array}{c}\text { Propensity- } \\
\text { Score-Matched } \\
\text { Nonrepurchasing } \\
\text { Firms } \\
\text { Mean } \\
\text { (Median) }\end{array}$ & $\begin{array}{c}\text { t-Test: } \\
t \text {-Statistic } \\
\text { (p-Value) }\end{array}$ & $\begin{array}{c}\text { Kruskal-Wallis } \\
\text { Test: } \chi^{2} \\
(p \text {-Value })\end{array}$ \\
\hline EPS is a factor in CEO bonus & 2,764 & $\begin{array}{c}599.48 \\
(356.76)\end{array}$ & $\begin{array}{c}518.21 \\
(267.03)\end{array}$ & $\begin{array}{c}4.13 \\
(<0.0001)\end{array}$ & $\begin{array}{c}15.65 \\
(<0.0001)\end{array}$ \\
\hline EPS is not a factor in CEO bonus & 1,251 & $\begin{array}{c}350.60 \\
(199.20)\end{array}$ & $\begin{array}{c}363.74 \\
(189.73)\end{array}$ & $\begin{array}{c}0.61 \\
(0.54)\end{array}$ & $\begin{array}{c}0.08 \\
(0.78)\end{array}$ \\
\hline
\end{tabular}

The results in Tables 8 and 9 consistently support Hypothesis 2: When a bonus award is based on EPS, CEOs in firms with positive net repurchases receive more bonus than those in nonrepurchasing firms, after controlling for various firm characteristics. The group of firms whose CEO bonus is not determined by EPS provides a useful benchmark: Share repurchase itself does not increase CEO bonus when EPS is not a factor in the bonus structure. The evidence supports the hypothesis that the bonus structure can create a personal motivation for CEOs to initiate share buyback. 


\section{Postbuyback Returns}

Our tests of the first two hypotheses establish that EPS-linked bonuses cause firms to repurchase more and their CEOs to benefit from higher bonuses as a result. Our final hypothesis predicts that because these repurchases are motivated differently from other repurchases, the postannouncement abnormal returns will be different as well. Specifically, to test Hypothesis 3, we study the 3-year abnormal returns following the end of the buyback announcement month. We collect the repurchase announcements from the Thomson Securities Data Company (SDC) Platinum database.

For each month, we form value-weighted portfolios of firms that have announced a buyback within the previous 3 years. The value-weighted monthly returns use the market value of equity at the end of the previous month as the weighting factor. The portfolios are rebalanced monthly so that all companies that reach the end of their 3-year period can be dropped and all companies that have just announced repurchases can be added. Using the calendar-time portfolio approach, we perform a standard 4-factor regression of monthly returns, dropping months with fewer than 10 firms to mitigate the heteroskedasticity problem (e.g., Mitchell and Stafford (2000)). The portfolio excess returns are regressed onto the 4 factors as introduced by Fama and French (1993) and Carhart (1997):

$$
R_{\text {buy }, t}-R_{f, t}=\alpha_{0}+\alpha_{1}\left(R_{m, t}-R_{f, t}\right)+\alpha_{2} S M B_{t}+\alpha_{3} H M L_{t}+\alpha_{4} U M D_{t}+\varepsilon_{t} .
$$

We also construct a zero-investment (or hedged) calendar-time portfolio consisting of long positions on repurchasing firms and short positions on their matching firms. For each event firm, we find a matching nonrepurchasing firm in the same industry with the closest firm size (measured by total assets). We estimate the regression of the hedged portfolio returns onto the 4 factors as well:

$$
R_{\text {buy }, t}-R_{\text {match }, t}=\gamma_{0}+\gamma_{1}\left(R_{m, t}-R_{f, t}\right)+\gamma_{2} S M B_{t}+\gamma_{3} H M L_{t}+\gamma_{4} U M D_{t}+\eta_{t} .
$$

The above analysis is also done for two subsets of firms: those with CEO bonus tied to EPS, and those with CEO bonus not tied to EPS. The estimated coefficients and standard errors are reported in Table 10.

For the sample of all repurchasing firms, the intercept, $\alpha_{0}$, is $0.31 \%$, which translates to a mean annual abnormal return of $3.7 \%$. $\gamma_{0}$ is $0.48 \%$, which means that the repurchasing firms outperform their matched firms by $5.76 \%$ annually. The results are qualitatively consistent with Ikenberry et al. (1995), although our sample period and methodology are different from theirs.

For the subset of the firms with CEO bonus tied to EPS, $\alpha_{0}$ and $\gamma_{0}$ are $0.01 \%$ and $0.29 \%$, respectively, not statistically significant. By contrast, for the subset of the firms with CEO bonus not tied to EPS, $\alpha_{0}$ and $\gamma_{0}$ are $0.45 \%$ (significant at $1 \%$ level) and $0.59 \%$ (significant at $5 \%$ level), respectively. These numbers translate to mean annual abnormal returns of $5.40 \%$ and $7.08 \%$, respectively.

This evidence provides support for Hypothesis 3, and it provides further support for our conclusion about the link between EPS-based bonuses and repurchasing activity. When a CEO's bonus is determined by EPS, shares of repurchasing firms do not outperform shares of their matching nonrepurchasing firms in the 
TABLE 10

3-Year Postbuyback Abnormal Returns

In Table 10, we collect the buyback announcements from the Thomson SDC Platinum database. We follow firms during the 3 years after the end of the announcement month. For each repurchasing firm, we also find a matching nonrepurchasing firm in the same industry with the closest firm size (measured by total assets). Using the calendar-time portfolio approach, we perform the following 4 -factor regressions of monthly returns.

$$
\begin{aligned}
R_{\text {buy }, t}-R_{f, t} & =\alpha_{0}+\alpha_{1}\left(R_{m, t}-R_{f, t}\right)+\alpha_{2} S M B_{t}+\alpha_{3} H M L_{t}+\alpha_{4} U M D_{t}+\varepsilon_{t}, \\
R_{\text {buy }, t}-R_{\text {match }, t} & =\gamma_{0}+\gamma_{1}\left(R_{m, t}-R_{f, t}\right)+\gamma_{2} S M B_{t}+\gamma_{3} H M L_{t}+\gamma_{4} U M D_{t}+\eta_{t} .
\end{aligned}
$$

$R_{\text {buy, } t}$ is the value-weighted portfolio return of repurchasing firms in month $t ; R_{\text {match, } t}$ is the value-weighted portfolio return of matching firms in month $t$. The numbers in parentheses are standard errors. The standard errors are robust to

\begin{tabular}{|c|c|c|c|c|c|c|c|}
\hline & $\underline{\text { Intercept }}$ & $\begin{array}{c}\text { Excess Market } \\
\text { Return } \\
\end{array}$ & Size & $\begin{array}{c}\text { Book-to- } \\
\text { Market Ratio } \\
\end{array}$ & Momentum & $n$ & $R^{2}$ \\
\hline \multicolumn{8}{|c|}{ All Repurchasing Firms } \\
\hline$R_{\text {buy }, t}-R_{f, t}$ & $\begin{array}{l}0.0031^{\star \star} \\
(0.0015)\end{array}$ & $\begin{array}{l}0.95^{\text {** }} \\
(0.04)\end{array}$ & $\begin{array}{r}-0.08 \\
(0.05)\end{array}$ & $\begin{array}{r}-0.12^{*} \\
(0.07)\end{array}$ & $\begin{array}{l}-0.12^{\star \star} \\
(0.04)\end{array}$ & 182 & 0.85 \\
\hline$R_{\text {buy }, t}-R_{\text {match }, t}$ & $\begin{array}{l}0.0048^{* *} \\
(0.0022)\end{array}$ & $\begin{array}{c}-0.05 \\
(0.06)\end{array}$ & $\begin{array}{l}-0.28^{\star \star \star} \\
(0.08)\end{array}$ & $\begin{array}{l}-0.40^{\star * *} \\
(0.09)\end{array}$ & $\begin{array}{c}0.04 \\
(0.05)\end{array}$ & 182 & 0.18 \\
\hline \multicolumn{8}{|c|}{ Repurchasing Firms with CEO Bonus Tied to EPS } \\
\hline$R_{\text {buy }, t}-R_{f, t}$ & $\begin{array}{c}0.0001 \\
(0.0027)\end{array}$ & $\begin{array}{l}1.09^{\star \star \star} \\
(0.06)\end{array}$ & $\begin{array}{l}0.18^{\star \star} \\
(0.08)\end{array}$ & $\begin{array}{r}-0.06 \\
(0.10)\end{array}$ & $\begin{array}{r}-0.09 \\
(0.07)\end{array}$ & 180 & 0.72 \\
\hline$R_{\text {buy }, t}-R_{\text {match }, t}$ & $\begin{array}{c}0.0029 \\
(0.0027)\end{array}$ & $\begin{array}{c}-0.06 \\
(0.07)\end{array}$ & $\begin{array}{c}-0.22^{\star \star} \\
(0.11)\end{array}$ & $\begin{array}{l}-0.43^{\star * *} \\
(0.10)\end{array}$ & $\begin{array}{r}-0.02 \\
(0.06)\end{array}$ & 180 & 0.11 \\
\hline \multicolumn{8}{|c|}{ Repurchasing Firms Whose CEO Bonus Is Not Tied to EPS } \\
\hline$R_{\text {buy }, t}-R_{f, t}$ & $\begin{array}{l}0.0045^{\star *} \\
(0.009)\end{array}$ & $\begin{array}{l}0.89^{\star \star \star} \\
(0.05)\end{array}$ & $\begin{array}{r}-0.08 \\
(0.07)\end{array}$ & $\begin{array}{c}-0.18^{* *} \\
(0.08)\end{array}$ & $\begin{array}{l}-0.20^{\star \star \star} \\
(0.04)\end{array}$ & 174 & 0.78 \\
\hline$R_{\text {buy }, t}-R_{\text {match }, t}$ & $\begin{array}{l}0.0059^{\star *} \\
(0.0030)\end{array}$ & $\begin{array}{r}-0.01 \\
(0.08)\end{array}$ & $\begin{array}{r}-0.07 \\
(0.10)\end{array}$ & $\begin{array}{l}-0.47^{\star \star \star *} \\
(0.11)\end{array}$ & $\begin{array}{c}0.05 \\
(0.09)\end{array}$ & 174 & 0.12 \\
\hline
\end{tabular}
heteroskedasticity. ${ }^{\star},{ }^{\star \star}$, and ${ }^{\star \star \star}$ indicate significance at the $10 \%, 5 \%$, and $1 \%$ levels, respectively.

postbuyback period. This fact is consistent with the implications of Hypotheses 1 and 2 that personal gain, rather than undervaluation, is the primary motivation for these repurchases.

\section{E. Additional Analyses}

In the Internet Appendix we present the results from examining whether discretionary accruals are complements or substitutes in managing EPS. We conclude that although each tool can manipulate EPS, they tend to be used by different firms or at different times for a given firm. We also present additional evidence that repurchases are accretive when they will affect the CEO's bonus. We further show that bonus-driven repurchases tend to happen toward the end of the year, when the need for them would be more certain. Finally, we include CEOs' portfolio deltas and find that they do not affect our results.

\section{Conclusion}

We investigate the direct financial incentives CEOs have to initiate repurchases. By mechanically increasing current-year EPS, repurchases provide a means for CEOs to increase their EPS-driven bonuses. In a hand-collected sample of more than 12,000 firm-years, we find support for the hypotheses that CEOs with EPS-based bonuses are more likely to repurchase and that the closer they are to their EPS bonus threshold, the greater is the effect. Hence, this study provides a link between share repurchases and CEO's private financial benefit. 
Our findings add to the literature linking earnings management and compensation as well as the literature establishing the influence of compensation on payout policy. Healy (1985) was the first to show that CEOs appear to manage earnings to meet bonus criteria. Our article extends his work by showing that with the rise of stock repurchases, CEOs now expend corporate liquidity on payout actions with the aim of manipulating bonus payouts. We further extend the literature, establishing that the design of CEO compensation influences payout policy. Earlier work in this area (e.g., Fenn and Liang (2001)) has shown that option compensation creates a preference for repurchases over dividends because options are not dividend protected. Our study shows that EPS-linked bonuses create an incentive to initiate a repurchase even in the absence of managerial options.

\section{Appendix A. Proxy Excerpts Regarding the Effect of Repurchasing on EPS-Linked Bonuses}

We first searched for keywords "repurchase," "repurchasing," or "share buyback" in the proximity of "EPS," "earnings-per-share," or "earnings per share" in the 6,125 proxies that link CEO bonus to earnings per share (EPS), and then we read the proxy if the computer located "repurchase," "repurchasing," or "share buyback" within a 100-word range from "EPS," "earnings-per-share," or "earnings per share" in that proxy. We found that in only 30 proxies (less than $0.5 \%$ of the 6,125 proxies), the firm's compensation committee talked about the impact of repurchase on EPS.

Among the 30 proxies, only 7 stated that they might adjust the impact of repurchase when deciding whether the EPS goal had been achieved. For example, Pepsi Bottling Group (PBG), in the proxy filed on Apr. 10, 2008, says:

For our business and industry, we believe the most relevant criteria on which to evaluate our success are earnings per share ("EPS"), profit, volume of product sold, and operating free cash flow (as defined in our earnings releases). We view EPS as the best composite indicator of PBG's operational performance. The Committee, therefore, emphasizes EPS in establishing performance targets for the Named Executive Officers. In evaluating our performance against such EPS targets, however, the Committee considers the impact of unusual events on our reported EPS results (e.g., acquisitions, changes in accounting practices, share repurchases, etc.) and may adjust the results for purposes of determining the extent to which the EPS targets were or were not achieved.

For the majority of the 30 proxies, the compensation committee understood the impact of repurchase on EPS, but they did not adjust the impact of repurchase when deciding whether EPS goal had been achieved. For example, Energizer, in the proxy filed on Nov. 29, 2007, says:

Our incentive programs are focused on consistent EPS growth from year to year. The choice of any performance metric involves a consideration of its advantages and drawbacks, and the committee has carefully considered these issues with respect to the use of EPS. The committee has recognized that non-operating factors, in particular our share repurchases over the past five years, have impacted EPS growth, even though the primary component of our EPS growth, historically, has been contributions from operations. We believe our share repurchase program has been an important factor in increasing shareholder value-a practical and tax efficient means of providing shareholder returns-and that our officers should be rewarded for its success. Consequently, the committee believes that it is appropriate to utilize EPS, without adjustment for share repurchases, as our key performance metric. Nevertheless, the committee is regularly advised of share repurchases and other discretionary management actions 
which can impact EPS growth. The committee also periodically considers the impact of our focus on EPS improvement on operational and cash management decisions.

\section{Appendix B. One Example of Bonus Plan}

The example below is obtained from the proxy statement of P. F. Chang's China Bistro Inc., filed Mar. 13, 2008:

The Company maintains an annual Officer Bonus Plan (the "Bonus Plan") designed to reward achievement of specified levels of financial and individual performance. Payouts, if any, under the Bonus Plan are based on the achievement by the Company of targeted earnings per share ("EPS") levels during the fiscal year. The Company believes that using EPS as the basis for determining payouts under the Bonus Plan closely aligns the compensation of the participants in the Bonus Plan with delivery of increased value to stockholders. The Committee chooses target EPS levels that are considered to be challenging. Under the Bonus Plan, each officer position has an assigned target bonus level, expressed as a percent of fiscal year-end annual base salary. If the Company achieves the targeted EPS level, then the targeted bonuses will be fully paid. The Committee approved the fiscal year 2007 Bonus Plan at its February 5, 2007 meeting. For fiscal year 2007, the target bonuses were 100\% for the Chief Executive Officer and the President (Richard Federico and Robert Vivian, respectively), 60\% for the Chief Financial Officer (Mark Mumford), 75\% for Executive Vice President and President of Pei Wei Asian Diner, Inc. (Russell Owens), and 60\% for the Executive Vice President and Chief Administrative Officer (Michael Welborn). The target EPS level for fiscal 2007 was $\$ 1.45$ per share. For fiscal year 2007, no payouts under the Bonus Plan were to be made unless the Company achieved at least $95 \%$ of the targeted EPS level, or $\$ 1.38$ per share, at which point participants would receive $65 \%$ of their target bonus level. As the Company did not achieve this minimum level of EPS for fiscal 2007, none of the named executive officers received a payout under the Bonus Plan for 2007.

\section{References}

Bagwell, L. "Share Repurchase and Takeover Deterrence." Rand Journal of Economics, 22 (1991), 72-88.

Bagwell, L., and J. Shoven. "Share Repurchases and Acquisitions: An Analysis of Which Firms Participate." In Corporate Takeovers: Causes and Consequences, A. G. Auerbach, ed. Chicago, IL: University of Chicago Press (1988), 191-213.

Bange, M., and W. De Bondt. "R\&D Budgets and Corporate Earnings Targets." Journal of Corporate Finance, 4 (1998), 153-184.

Banyi, M.; E. Dyl; and K. Kahle. "Errors in Estimating Share Repurchases." Journal of Corporate Finance, 14 (2008), 460-474.

Bens, D. A.; V. Nagar; D. Skinner; and M. Wong. "Employee Stock Options, EPS Dilution, and Stock Repurchases.” Journal of Accounting and Economics, 36 (2003), 51-90.

Brav, A.; J. Graham; C. Harvey; and R. Michaely. "Payout Policy in the 21st Century." Journal of Financial Economics, 77 (2005), 483-527.

Brennan, M., and A. Thakor. "Shareholder Preferences and Dividend Policy." Journal of Finance, 45 (1990), 992-1017.

Brown, D., and M. Ryngaert. "The Mode of Acquisition in Takeovers: Taxes and Asymmetric Information.” Journal of Finance, 46 (1991), 653-669.

Bushee, B. "The Influence of Institutional Investors on Myopic R\&D Investment Behavior.” Accounting Review, 73 (1998), 305-333.

Carhart, M. “On Persistence in Mutual Fund Performance.” Journal of Finance, 52 (1997), 57-82.

Denis, D. "Defensive Changes in Corporate Payout Policy: Share Repurchases and Special Dividends." Journal of Finance, 45 (1990), 1433-1456. 
Doyle, J.; W. Ge; and S. McVay. "Accruals Quality and Internal Control over Financial Reporting." Accounting Review, 82 (2007), 1141-1170.

Easterbrook, F. H. "Two Agency-Cost Explanations of Dividends." American Economic Review, 74 (1984), 221-230.

Fama, E., and K. French. "Common Risk Factors in the Returns on Stocks and Bonds." Journal of Financial Economics, 33 (1993), 3-56.

Fama, E., and K. French. "Disappearing Dividends: Changing Firm Characteristics or Lower Propensity to Pay?" Journal of Financial Economics, 60 (2001), 3-43.

Fenn, G. W., and N. Liang. "Corporate Payout Policy and Managerial Stock Incentives.” Journal of Financial Economics, 60 (2001), 45-72.

Francis, J.; C. Lennox; and Z. Wang. "Selection Models in Accounting Research.” Accounting Review, 87 (2012), 589-616.

Gompers, P.; J. Ishii; and A. Metrick. "Corporate Governance and Equity Prices.” Quarterly Journal of Economics, 118 (2003), 107-155.

Grullon, G., and R. Michaely. "Dividends, Share Repurchases and the Substitution Hypothesis." Journal of Finance, 57 (2002), 1649-1684.

Guay, W., and J. Harford. "The Cash-Flow Permanence and Information Content of Dividend Increases versus Repurchases.” Journal of Financial Economics, 57 (2000), 385-415.

Guidry, F.; A. J. Leone; and S. Rock. "Earnings-Based Bonus Plans and Earnings Management by Business-Unit Managers.” Journal of Accounting and Economics, 26 (1999), 113-142.

Healy, P. "The Effect of Bonus Schemes on Accounting Decisions." Journal of Accounting and Economics, 7 (1985), 85-107.

Hribar, P.; N. Jenkins; and B. Johnson. "Stock Repurchases as an Earnings Management Device." Journal of Accounting and Economics, 41 (2006), 3-27.

Ikenberry, D.; J. Lakonishok; and T. Vermaelen. "The Underreaction to Open Market Share Repurchases." Journal of Financial Economics, 39 (1995), 181-208.

Jagannathan, M.; C. Stephens; and M. Weisbach. "Financial Flexibility and the Choice between Dividends and Stock Repurchases.” Journal of Financial Economics, 57 (2000), 355-384.

Jensen, M. “Agency Costs of Free Cash Flow." American Economic Review, 76 (1986), 323-329.

Jensen, M. "The Modern Industrial Revolution, Exit, and the Failure of Internal Control Systems." Journal of Finance, 48 (1993), 831-880.

John, K., and J. Williams. "Dividends, Dilution and Taxes: A Signaling Equilibrium." Journal of Finance, 40 (1984), 1053-1070.

Kahle, K. "When a Buyback Isn't a Buyback: Open Market Repurchases and Employee Stock Options." Journal of Financial Economics, 63 (2002), 235-261.

Kruskal, W., and A. Wallis. "Use of Ranks in One-Criterion Variance Analysis." Journal of the American Statistical Association, 47 (1952), 583-621.

LaLonde, R. "Evaluating the Econometric Evaluations of Training Programs with Experimental Data." American Economic Review, 76 (1986), 604-620.

Lie, E. "Do Firms Undertake Self-Tender Offers to Optimize Capital Structure?" Journal of Business, 75 (2002), 609-639.

Lucas, D., and R. McDonald. "Shareholder Heterogeneity, Adverse Selection and Payout Policy." Journal of Financial and Quantitative Analysis, 33 (1998), 233-253.

Marquardt, C.; C. Tan; and S. Young. "Accelerated Share Repurchases, Bonus Compensation, and CEO Horizons.” Working Paper, available at http://ssrn.com/abstract=1346624 (2010).

Matsunaga, S., and C. Park. "The Effect of Missing a Quarterly Earnings Benchmark on the CEO's Annual Bonus.” Accounting Review, 76 (2001), 313-332.

Mitchell, M., and E. Stafford. "Managerial Decisions and Long-Term Stock Price Performance." Journal of Business, 73 (2000), 287-329.

Opler, T., and S. Titman. "The Debt-Equity Choice: An Analysis of Issuing Firms.” Working Paper, Ohio State University (1996).

Petersen, M. "Estimating Standard Errors in Finance Panel Data Sets: Comparing Approaches." Review of Financial Studies, 22 (2009), 435-480.

Peyer, U., and T. Vermaelen. "The Nature and Persistence of Buyback Anomalies." Review of Financial Studies, 22 (2009), 1693-1745.

Richardson, S.; S. H. Teoh; and P. Wysocki. "The Walk-Down to Beatable Analyst Forecasts: The Role of Equity Issuance and Insider Trading Incentives." Contemporary Accounting Research, 21 (2004), 885-924.

Roychowdhury, S. "Earnings Management through Real Activities Manipulation." Journal of Accounting and Economics, 42 (2006), 335-370.

Shleifer, A., and R. Vishny. "Large Shareholders and Corporate Control." Journal of Political Economy, 94 (1986), 461-488. 
Skinner, D. "The Evolving Relation between Earnings, Dividends, and Stock Repurchases." Journal of Financial Economics, 87 (2008), 582-609.

Vermaelen, T. "Common Stock Repurchases and Market Signaling: An Empirical Study." Journal of Financial Economics, 9 (1981), 139-183.

Young, S., and J. Yang. "Stock Repurchases and Executive Compensation Contract Design: The Role of Earnings per Share Performance Conditions.” Accounting Review, 86 (2011), 703-733. 